\title{
TRAFFIC SPEED REPORT NO. 86
}

\section{SEPTEMBER 1968}

NO. 17

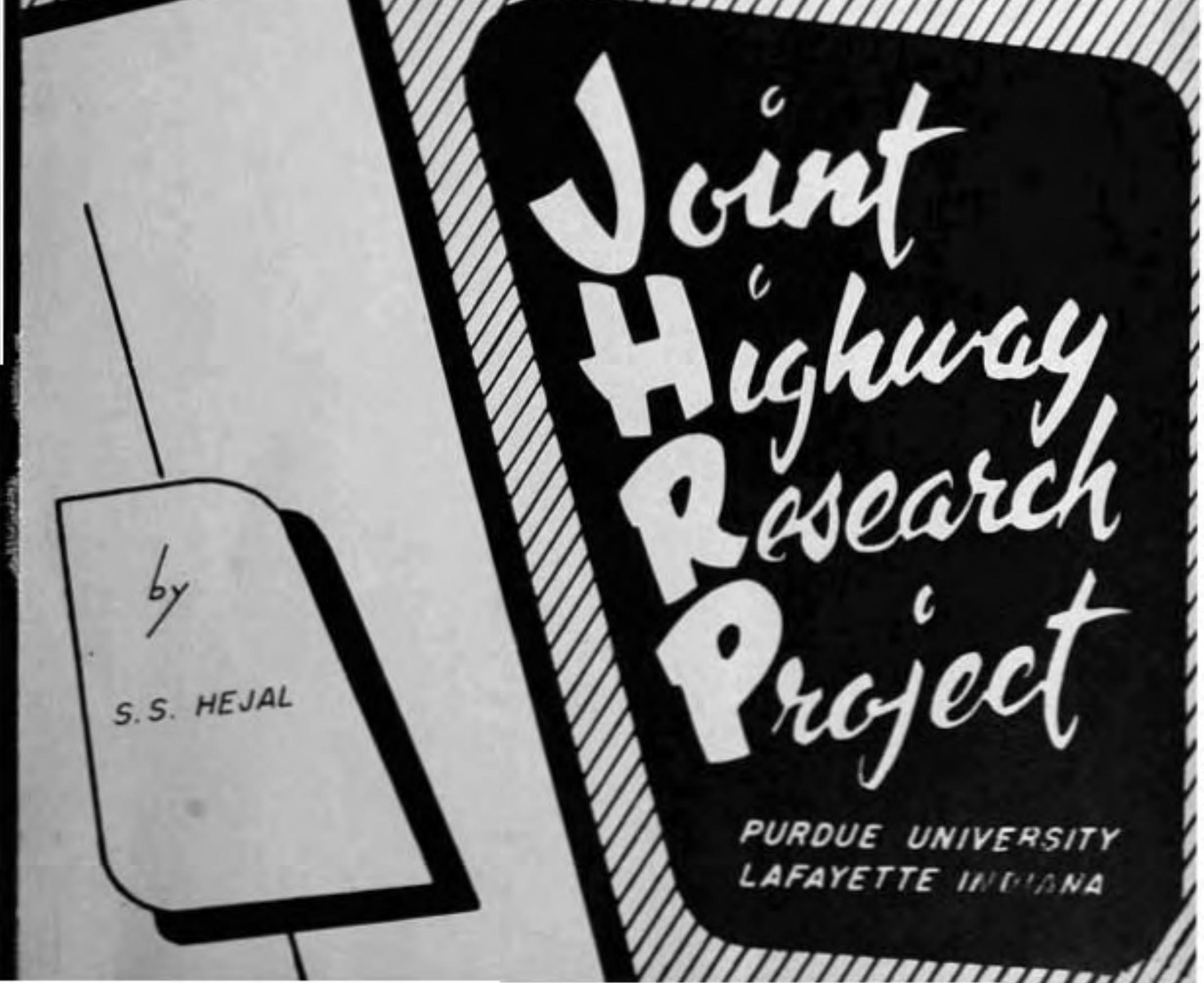


To:

J. F. Motaughlin, Director

Jolut Highriey Receerch Project

Pron: Z, I. Kiobael, Associate Director Jo1nt Fighray Researeh Project

Septenher 12, 1968

F19: $8-3-3$

Project: C-36-100

The attached Progress Report Nio. 86 ca Traffle Speads is the report of the 1968 study of free-flovine axtorobile and truek speeds on rural, thngent, lovel secticns of Interstate, otber 4-lane and 2-lone hilgumys in Indiane. The study and report have been perforned by lis. Salin S. Hefal, a Graduate Instructor in Ilesaarch on our starf, under the direction of Professor Vichael.

The resuits indicate sisilar average speeda for all passenger care and an incroase of about 2.5 mph for all heavy trucks to those speeds noted in the 1967 study. A regrosston analysis of the speed dats for the past eleven years indicated that the spead trend for all classes of vehicles on all classes of hifhuxy stutled is an increesing one. Avaruge apeeds for passenger cars ovor all clsssee of hithuay have increased 0.85 mph annually and for a.l1 heavs trucks over all clacees of hifhray the increase has beon $0.07 \mathrm{mph}$ annually.

Coples of this repoit are requestad for releose to the Indiane State Police, the Indiana Trafric Safety Counc1l and the Indiana OPflce of Traffle Safoty as is nornal procedure for these reports. Copies will also be sent to the Bureau of Public Roeds and several Departinents uthin the IsHC. The repoit is prosented for the record and for reloase as noted.

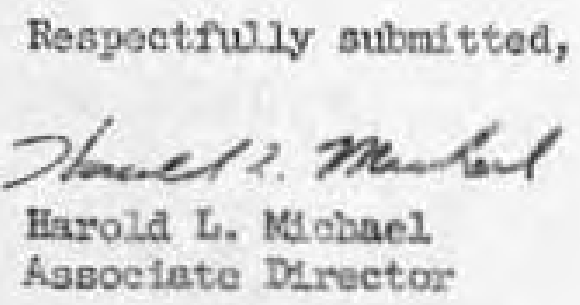

HEM:lh

Attachnent

Copy: 7. T. Ashbeucher

v. L. Dolch

ห. ม. Gootz

1. L. Orecco

G. K. HaUloek

M. B. Harr
B. H. Harre11

J. A. Havers

v. B. Harvey

G. A. Lecnarde

7. B. Mendenho11

R. D. Hiles

J. C. Oppeninnder c. P. Scholer

N. B. Scott

V. 7 . Epencer

II. R. J. Walsh

K. B. Woods

E. J. Yoder 


\section{Digitized by the Internet Archive}

\section{in 2011 with funding from}

LYRASIS members and Sloan Foundation; Indiana Department of Transportation
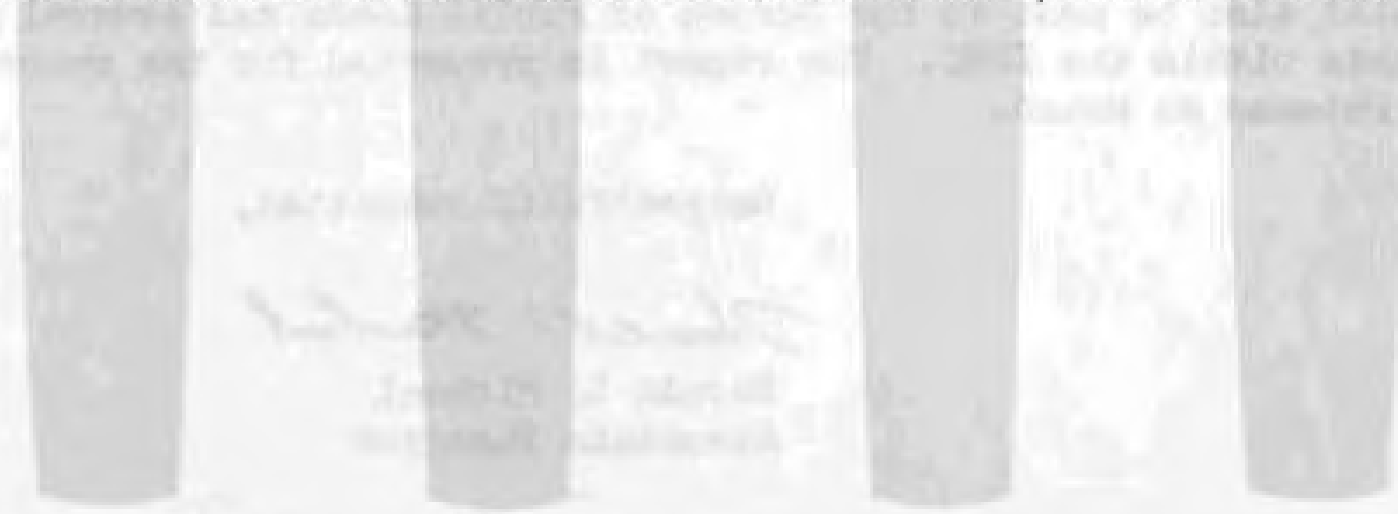
Progress Report

TRAFFIC SPESD REPORT NO. 86

\author{
by \\ Salin S. Hejal \\ Gracuate Assistant
}

Joint Highnay Research Project

File No.: 8-3-3

Project Ho.: C-36-10C 


\section{ABSTRACT}

This report is the annual continuing study of the speeds of vehicles on rurel Indiape high:ays. Observations of spot epeeds sere taken on interstate, other four lane, and t:o lene highays throughout the state during the months of June and July, 1968.

Aralysis of the speeds showed the over-all average speed for passenger cars vas 64.5 miles per hour. The over-all averege speeds for trucks on the firree types of highueys vas 56.5 miles per hour.

A regression analysis on the aveilable results of the pase eleven years ahoved an annual increase of 0.85 atles per hour for the over-all average speed of pessenger cars and $0.87 \mathrm{~m} 11$ es per hour for the over-all average speed of heavy truclas. 
TRATIIC SPBSD REPORT NO. 86

Th1s report is an analysis of spot speed observations made during June and July 1968. All observations vere ade of free-flouing vehfeles on level, tangent sections of rural Indiana high:ays during daylight and under favorable veather conditions. The same locations on selected Federal and State high:ays as used in 1967 vere used aEain. Noot of these locations have been the sane for many years. Staticns vere claselfied as - two lane, four lene, or interstate highLays. A ropresentative sanple of traffic speeds us obtained at each of the four stations in each classification. The specifle site of each station was as follous: (see Figure A)

Interstate Hilghioys

1. I-69 3.3 161es South of Junction of S. R. 18

2. I-65 1.0 Miles West of Junction of S. R. $33^{4}$

3. I $-74 \quad 1.0$ Mile East of Junction of Post Road

4. I-65 2.9 Miles North of Junction of S. B. 160

Bour Iane H1 ghvers

5. v. S. $31 \quad 1.2$ Mfles South of Junetion of S. R. 38

6. U. S. 521.0 Whle Dast of Junction of S. R. 28

7. U. 8. $41 \quad 1.0$ Mile North of South Juaction of S. R. 2

8. U. S. $52 \quad 1.0$ Vale West of Konaike

Tho Lane Highrsys

9. v. S. $41 \quad 1.0$ Nite North of Boewe11

10. S. R. $43 \quad 2,0$ Wiles South of Chalmera

11. U. S. 313.0 N1es South of Rochester

12. 8. R. 250.7 thiles West of Abericus 
The vehicles vere classiffed as passenger cars or trucks. Passenger cars vere further classifled Into two groups - Indiann or NonIndiana and the analysis vas performed as thus classifled and combined. The trucks were also elassifled into two groups - Ldght (less than 5000 pounds gross velght) or Heavy (equal to or more than 5000 pounds Gross velght), and again the anslysis vas performod as classiffed and comblned.

The mudan speed linits in Indiana are as follows: 70 alles per hour on interstete highays and $65 \mathrm{mlles}$ per hour on other highvays, unless otherulse posted. This is the second yoar that track speed 1inits were the sane as passenger cars. The statod maximua speed 1imits vere applicable et all interstete, four lane and two lane stations or this study.

\section{Equipment and Fleld Procedure}

The observations for this report were obtained by use of an "Blectromatic" Radar Speed Meter, built by Automat1c S1gnal Division, Bastman Inaustries, Inc., Bast Norva1k, Connecticut. The meter vas placed approximately four feet from the edge of the pavament at an angle less than $10^{\circ}$ with the highiay center line. Speed inaccuracles are negliGible at sma11 angles (less than $10^{\circ}$ ) and therefore, corrections for angle vere unnecessary.

At the beginning of the study the accuracy of the mater ins checkad; a constant discrepency of minus two miles per hour uas found and hence all readings of speed vere corrected accordingly.

\section{Results of Anatyois}

The deta collected vere analyzed and are sumarlsed in Tables 1 to 12 in the Appendix. Tables 13, 14, and 15 aumerite the data for 


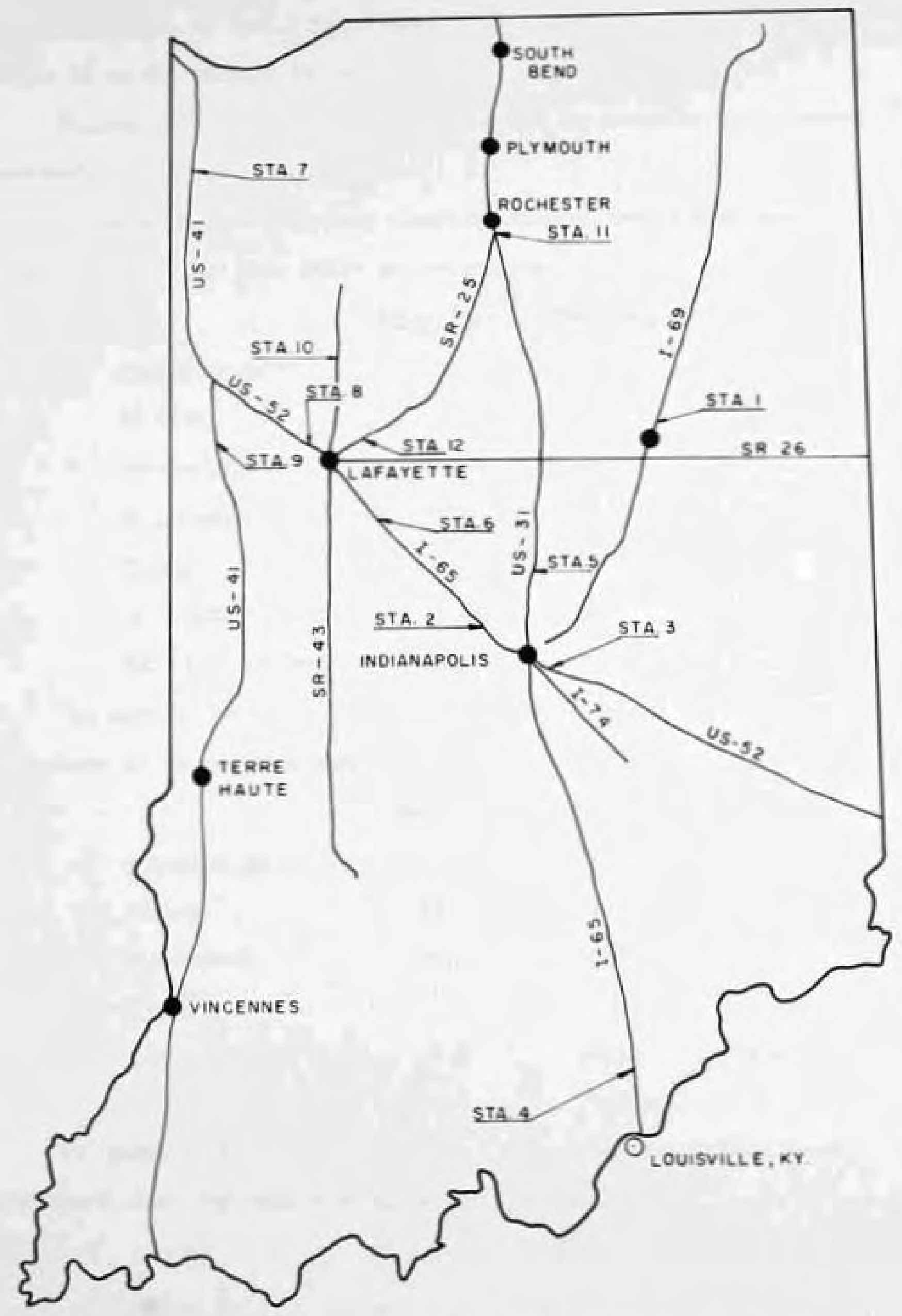

FIG. A - LOCATIONS OF SPEED-STUDY STATIONS 
the three types of fecilities: Interstete, four luns, and tvo lane. Table 16 is the sunuary for all factlittes obsemred.

Figures 1 to 16 in the Appendix shov the accurniativa apesd curvea for each of the staticns studied.

The avenge apeed for each classifleation of rohtoler on cach type of highiay for this study vas as follous:

\section{Interstate Posw Inne 5vo Iane}

\section{Pagnenger cars:}

Inasina

Non-Indiann

85 percentlle (ail)

Trucka:

less than $5000 \mathrm{lbs}$.

5000 lbs. or more
66.1

67.9

72.4

60.5

57.9
64.2

66.2

$70 . h^{2}$

58.4

55.4
6.2 2

$6 e .4$

68.1

The parcent of vehicles exceating the spoed linit for cach class1ffeation of vehicle and each type of hiftrvay was as folich:

Interetate Bour lane two lane

Passenger cara:

Indiane

23.1

42.6

24.7

Ion-Inatana

32.2

56.8

32.3

Trueks:

loss than $5000 \mathrm{lbs}$.

T.0

$24 \cdot 3$

7.2

5000 the. or wore

0.3

4.9

3.5

Tho perocat of volicles traveling 5 atles per hour or sors above the apond list for coch eape us at follorv: 
Intersiele Four Inge lyo Ing:

Pagsenges cara:

$\begin{array}{lccc}\text { Indians } & 5.2 & 14.7 & 9.6 \\ \text { Nlon-Inalans } & 8.0 & 19.5 & 6.1 \\ \text { Truckas: } & & & \\ \text { less than } 5000 \text { Ibs. } & 1.0 & 4.4 & 0.7 \\ 5000 \text { Ibs. or moro } & 0.3 & 0.7 & 0.5\end{array}$

The results of this atudy and sintlar stulies concucted since 1958 are tabulated in Table A. A linear rogrosaion ansyels on these resulte uns conducted and a sumary is given in Thbla B.

The hypotheele $\beta=0$, were $\beta$ is the slope of the lincer greph of spesâs versus yoar (annual trend), vas tastod and ft turned out significant for all elassifications st the for loval. Another hypothesis $\beta=1.0$ vae tested to drav lints on the amna), trand. It lae significant in only 4 cases and not sienificant in the rest using the same level of significnace as the previout lypothesis.

A graphicel ropresentation of tables $B$ and $B$ is glven in Figure B. 
(Tree-Hoving Vehicles on Level. Tangant Sectiona)

\begin{tabular}{|c|c|c|c|c|c|c|c|c|}
\hline & & & & & & & & \\
\hline & & $\begin{array}{l}\text { Iod. } \\
\text { Yaan }\end{array}$ & $\begin{array}{l}\text { Maa-Ied. } \\
\text { Yean }\end{array}$ & $\begin{array}{l}\text { A11 } \\
\text { Hean }\end{array}$ & A11 & $\begin{array}{l}\text { Light } \\
\text { Yena }\end{array}$ & $\begin{array}{l}\text { Basvy } \\
\text { Moan }\end{array}$ & $\begin{array}{l}\text { A11 } \\
\text { Yegn }\end{array}$ \\
\hline $10-201$ & Righasya & & & & & & & \\
\hline Aug. & 158 & 54.3 & 56.3 & 55.0 & 61.7 & 53.0 & 46.3 & 47.8 \\
\hline Aus. & 159 & 55.6 & 55.3 & 55.9 & 63.2 & 49.7 & 46.7 & 48.0 \\
\hline Sept. & 160 & 55.7 & 55.6 & 55,6 & 62.0 & 53.0 & 48.1 & 49.1 \\
\hline Aug. & 61 & 56.2 & 55.7 & 55.8 & 62.2 & 50.6 & 48.9 & 49.3 \\
\hline Augs. & 162 & 56.7 & 57.5 & 57.0 & 63.7 & 53.1 & 49.3 & 50.1 \\
\hline June & 163 & 56.9 & 57.7 & 57.2 & 64.0 & 52.3 & 47.9 & 49.7 \\
\hline July & 164 & 59.1 & 60.1 & 59.5 & 56.6 & 53.9 & 51.7 & 52.4 \\
\hline Sept. & 65 & 58.2 & 57.9 & 58.1 & 64.6 & 54.3 & 50.6 & 51.7 \\
\hline sept. & $' 65$ & 60.1 & 59.5 & 59.9 & 65.5 & 55.4 & 50.8 & 52.0 \\
\hline Aug. & 167 & 61.0 & 61.9 & 61.3 & 68.0 & 53.8 & 51.9 & 52.7 \\
\hline Inn? & 168 & 61.2 & 62.4 & 61.5 & 68.1 & 34.4 & 54.2 & 54.3 \\
\hline Pour-Las & 2 El zirvays & & & & & & & \\
\hline Aug. & 138 & 58.0 & 59.6 & 58.7 & 55.0 & 54.3 & 49.0 & 50,0 \\
\hline Aug. & 159 & 58.4 & 60.1 & 59.1 & 54.5 & 50.0 & 53.1 & 49.5 \\
\hline Sept. & 160 & 59.5 & 60.2 & 59.7 & 65.8 & 54.8 & 51.3 & 52.0 \\
\hline Aug. & .61 & 57.6 & 57.6 & 57.6 & 63.5 & 53.6 & 50.3 & 51.0 \\
\hline Aug. & 162 & 59.2 & 59.3 & 59.2 & 65.8 & 54.7 & 51.3 & 51.9 \\
\hline June & 63 & 60.4 & 60.6 & 60.5 & 66.3 & 55.0 & 48.6 & 51.3 \\
\hline July & 164 & 61.4 & 63.0 & 62.0 & 69.4 & 55.1 & 54.5 & 54.7 \\
\hline Sept. & 165 & 60.1 & 62.2 & 61.0 & 67.2 & 55.5 & 53.1 & 53.7 \\
\hline sept. & 166 & 63.1 & 64.3 & 63.5 & 69.0 & 53.7 & 52.8 & 54.2 \\
\hline Aug. & 167 & 64.3 & 65.7 & 65.0 & 70.3 & 57.0 & 54.0 & 54.9 \\
\hline June & 168 & 64.2 & 66.2 & 64.9 & 70.4 & 58.4 & 55.4 & 56.2 \\
\hline Inserete & te Ifghvay & & & & & & & \\
\hline Aag. & 61 & 56.74 & 56.9 & 58.2 & 64.0 & 55.9 & 51.5 & 52.4 \\
\hline Aus. & 62 & 58.7 & 59.1 & 58.8 & 65.6 & 55.8 & 52.7 & 53.2 \\
\hline Juas & 163 & 59.7 & 61.2 & 60.3 & 66.3 & 55.2 & 51.5 & 52.7 \\
\hline Jaly & 164 & 61.9 & 64.0 & 62.7 & 70.5 & 56.8 & 54.6 & 55.2 \\
\hline Sept. & 65 & 61.2 & 62.1 & 51.5 & 67.7 & 54.9 & 53.6 & 53.9 \\
\hline Sept. & $' 66$ & 62.1 & 63.3 & 62.5 & 68.5 & 56.1 & 54.9 & 55.3 \\
\hline Atag. & 167 & 66.4 & 68.3 & 57.2 & 73.6 & 60.0 & 56.9 & 57.5 \\
\hline June & .68 & 66.2 & 67,9 & 66.8 & 72.4 & 60.5 & 57.9 & 58.5 \\
\hline 12 Fish & ya & & & & & & & \\
\hline AuE. & 158 & 55.7 & 37.9 & 56.5 & 53.1 & 53.4 & 47.5 & 48.7 \\
\hline Aug. & 159 & 56.5 & 58.4 & 57.4 & 63.5 & 50.6 & 47.8 & 48.6 \\
\hline Sept. & 160 & 57.3 & 57.6 & 57.4 & 63.7 & 53.7 & 49.4 & 50.2 \\
\hline Aug. & 61 & 56.9 & 56.7 & 57.3 & 63.4 & 53.1 & 50.3 & 52,0 \\
\hline Aug. & 162 & 58.2 & 58.7 & 58.4 & 65.1 & 54.5 & 51,2 & 51,8 \\
\hline June & 163 & 59.0 & 59.9 & 59.3 & 65.2 & 54.1 & 49.5 & $5 i=2$ \\
\hline July & '64 & 60.8 & 62,4 & 62.5 & 69.2 & 55.2 & 53.7 & 54,1 \\
\hline Sept. & 165 & 59.9 & 60.9 & 60.3 & 66.7 & 54.9 & 52,6 & 53.1 \\
\hline Sept. & ' 66 & 62.8 & 62.4 & 62.0 & 68.0 & 56.7 & 52.7 & 53.8 \\
\hline Aug. & 167 & 63.9 & 65.8 & 64.5 & 71.4 & 56.3 & 54.6 & 55.2 \\
\hline June & 68 & 63.8 & 66.0 & 34.5 & 70.8 & 57.2 & 56.2 & 56.5 \\
\hline
\end{tabular}




\begin{tabular}{|c|c|c|c|c|c|c|c|}
\hline i & & $60^{\circ}$ & (i) & $\because$ & & ${ }^{*}$ &. \\
\hline & $*$ & $=$ & (10 1. & $*_{\infty}$ & $*_{\infty}$ & $*_{\infty}$ & 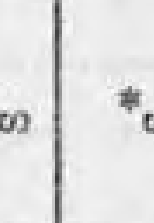 \\
\hline$\sigma^{\vec{A}}$ & \% & $\frac{3}{8}$ & : & 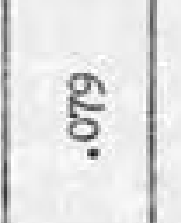 & 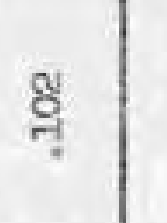 & $\frac{q}{q}$ & : \\
\hline of & 5 & : & 8 & 客 & $\$$ & $\approx$ & 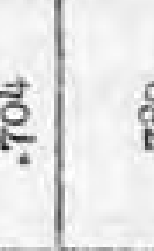 \\
\hline$\vec{s}$ & 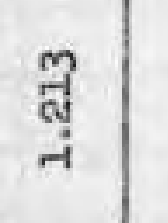 & 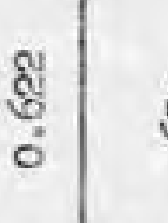 & : & 竞 & 8 & 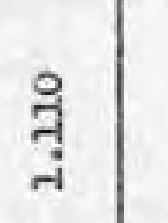 & 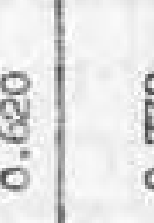 \\
\hline$\therefore$ & 8 & 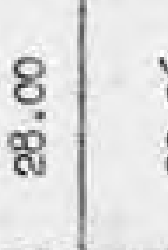 & 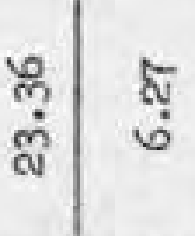 & $\frac{\mathbb{s}}{0}$ & po & ซึ. & 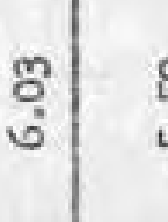 \\
\hline 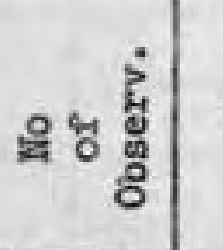 & & $\Rightarrow$ & $\Rightarrow \Rightarrow$ & $\Rightarrow$ & $A$ & $\circ$ & $\Rightarrow \Rightarrow$ \\
\hline & & & & $\begin{array}{c}8^{4} \\
\vdots\end{array}$ & & & \\
\hline
\end{tabular}




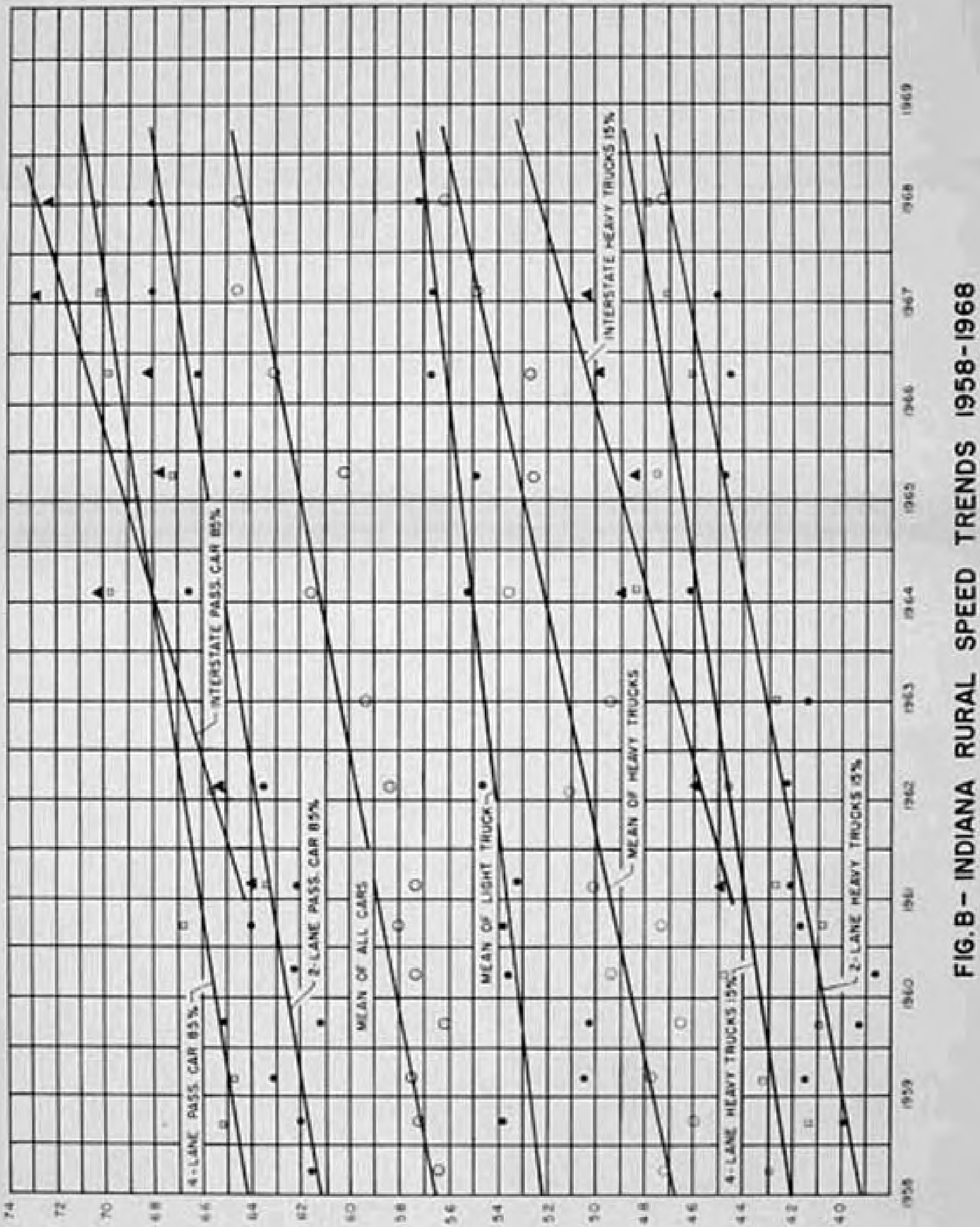




\section{Bummary and Conclusions}

The average speeds in this study vere found to be sinilar for pasbenger cars and 2.5 miles per hour Daster for trusks than the results of the previous year.

The Ifnear regresalon on the results of the past ten years proved that therv bas baen a definite increase in opeeds for all vehicle and hifhuay classifieations stuafed. The anmual trend for different speed characterioties such as 85 yercentiles, averoge speods, and 15 percenthles for passengur cors, lifitt trucks and heavy trucles on the three clesses of highuys reneod betseen 0.48 and 2.21 miler per hour inerease antually. For all paesenger cars the anninl inerease tas found to be 0.85 anles per hour for average speed and for all heavy trucks the annual increase in avarage speed tas found to be 0.87 miles por hour.

It is interesting to note that although the opoed limite for heavy trucks vas inorcesed by $15 \mathrm{~m} \cdot \mathrm{p} \cdot \mathrm{h}$. to the speed $2 \mathrm{mi}$ ts for automobilles on the highreys of Indians a year and a hale ago, no large Increase bas occurred in actual truck speeds. The effect of the change In opeed linsts for heavy trucks on actuel specd appears to be nogliglble. In other words, trucks travel at speeds their drivers consider safe, Irreopective of ancimum speed linits. The grourlng percentage of eutosobiles violating current rauimus speod linits especially on four-lane highveys, tends to support a similar statesent, namely that their drivers sleo select their travel speeds in the sene maner. 


\section{APPGIDX}




\section{Deterwination of Sauple sive}

It was dautred that a $95 \%$ confifience interval of the true nean of the apeeds of parsenger cers should not be wider then two utles per hour. Por trueise velghing 5,000 $1 \mathrm{ba}$. ox wre a $95 \mathrm{z}$ confidenee faterval with e four wle ger hour bend was desfred.

Aeauning a norasl distributton of speeds and veing the thandard deviation of the grouped data of the 1967 study, the atainus anple size requirearnt wat deterained by:

$$
x=\left[\frac{255}{i}\right]^{2}
$$

H = eaple of ze reçutred

$t$ - tabulated " $t "$ value for $5 / 2$ signifieence

$S$ = eationted standard devietion

$L=$ vidich of the intervel

For passenger cars:

$$
H=\left[\frac{2 \times 1.96 \times 7.5}{2}\right]^{2}=216 \text { obeervetions }
$$

Por trucke:

N $\left[\frac{2 \times 1.96 \times 6.9}{4}\right]^{2}=45$ olvervations

Fore

at all stations nore than 216 paesenger cax obervatione and 70 trueis observatlone were obtained for the study regotted herein. 


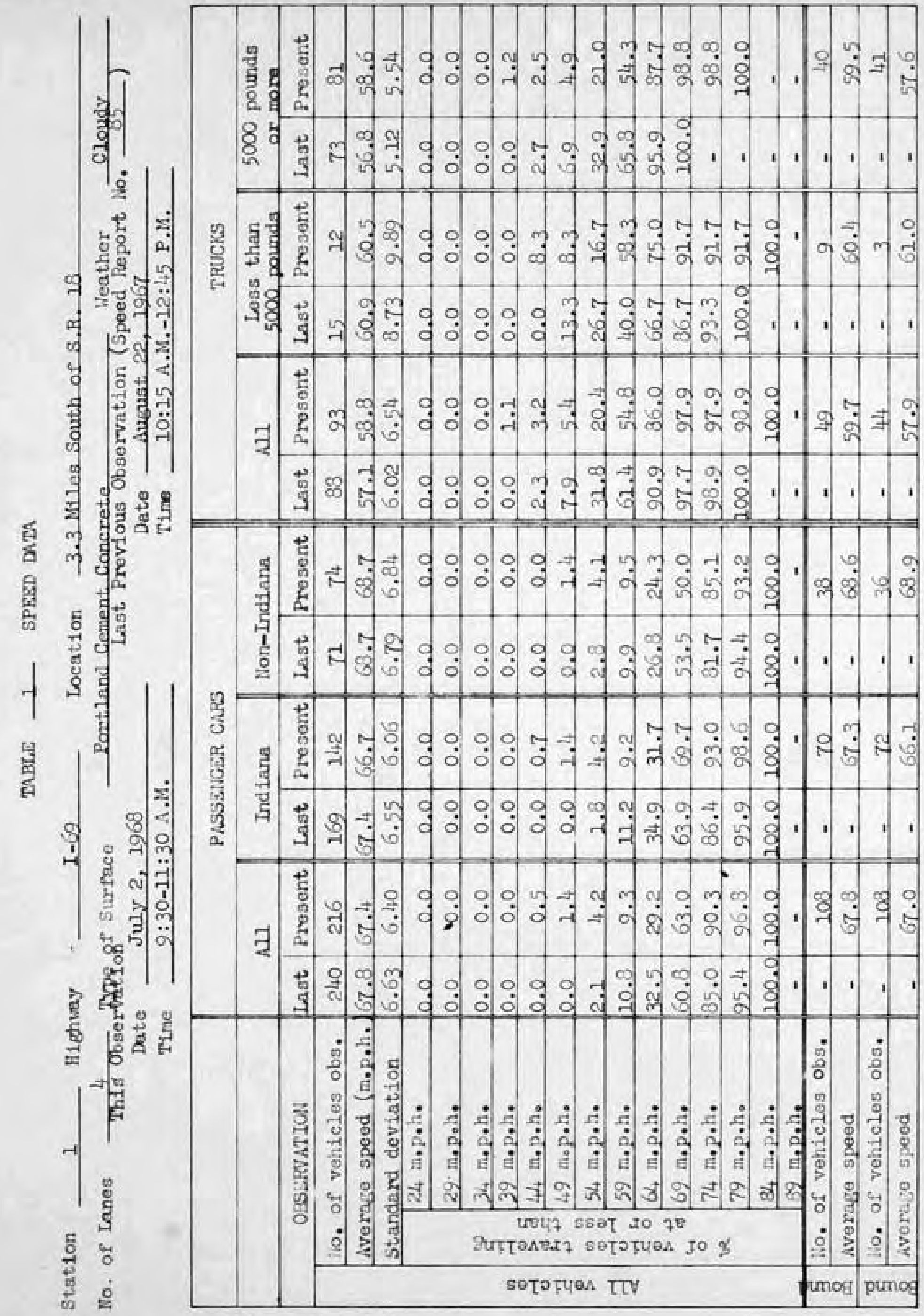




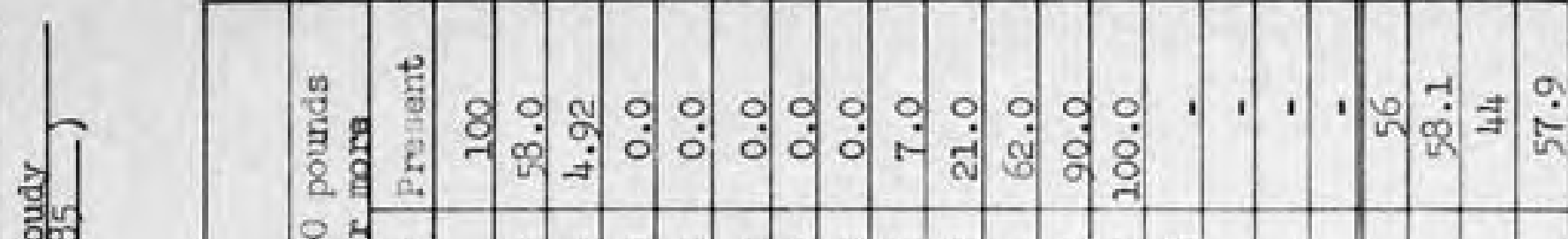

8 वै

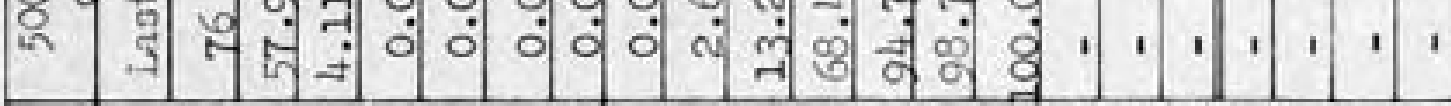

ल.

종 द्व:

ले

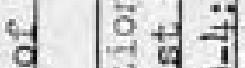

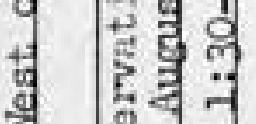

눙

ㄱ.

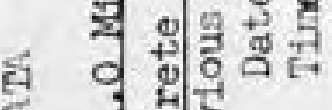

.

इ8्दु

a 7 ํํำ

있

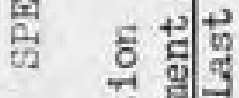

a

d. 9

है

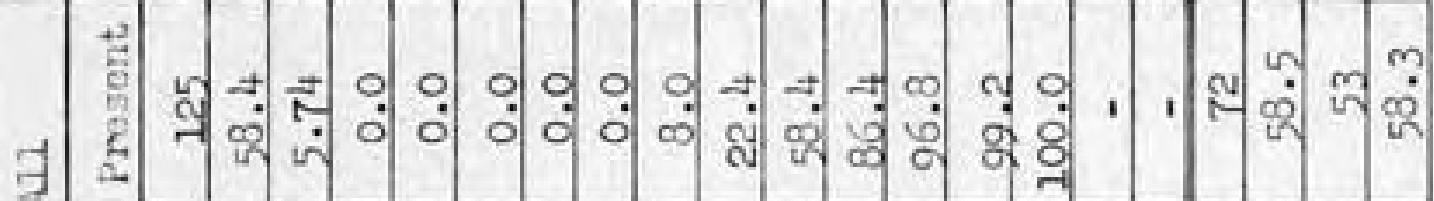

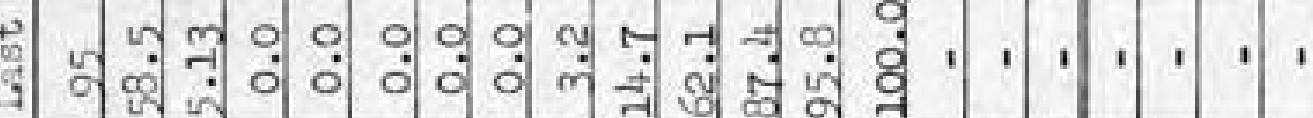

秀

兵 节

o.

잉 9

ơ

4 क्ष 0 के

$\Rightarrow$ \&

5.

:

|

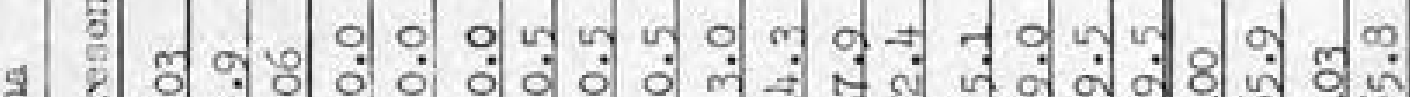

दू ती

苛

2 जी जी

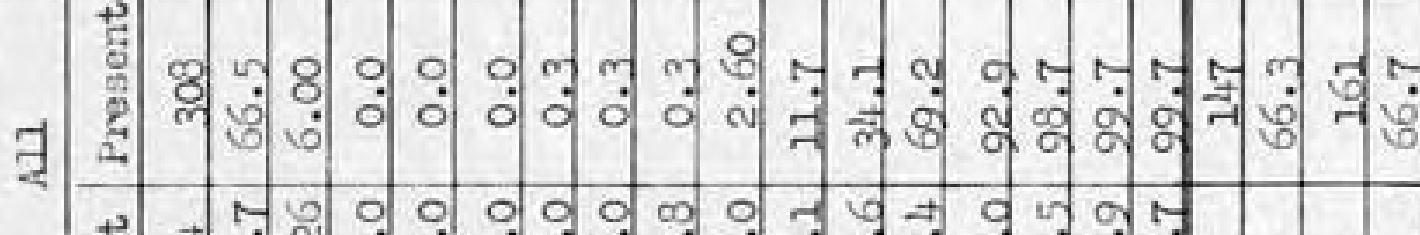

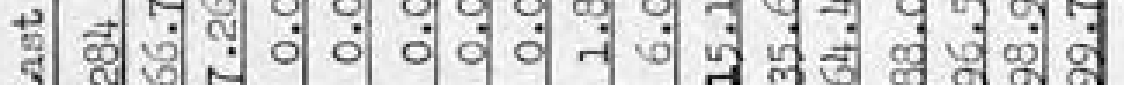

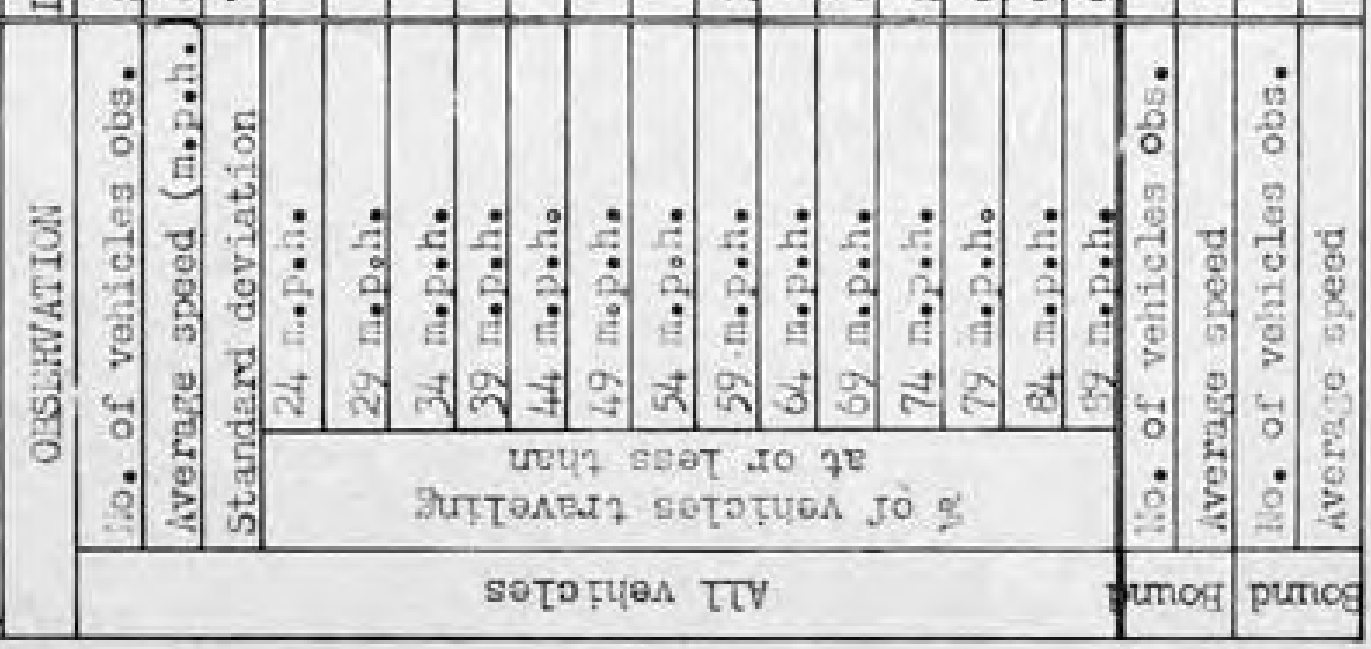




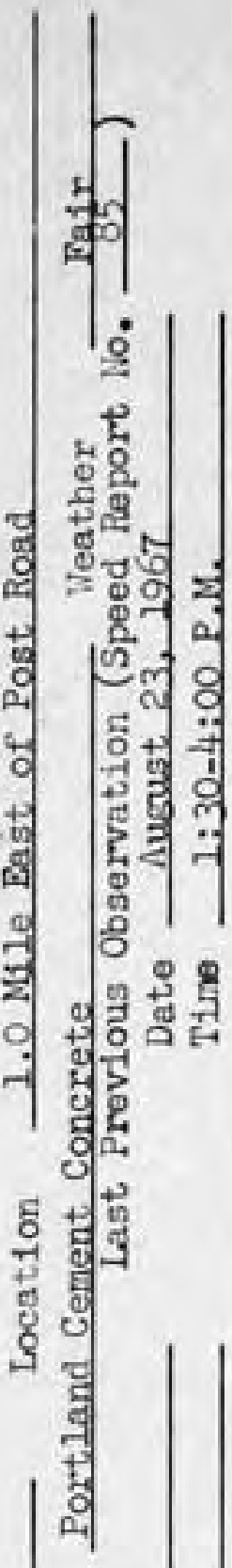

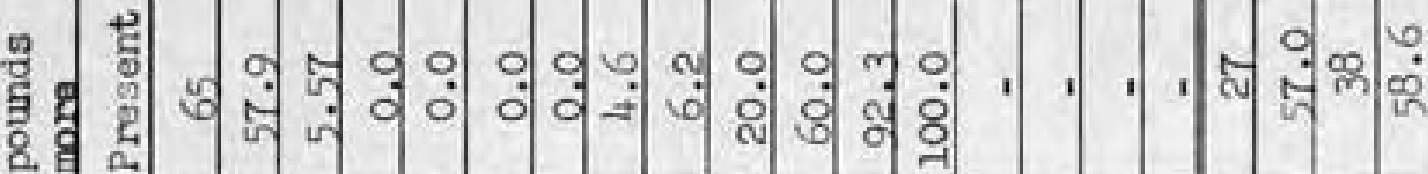

8 ํㅐ

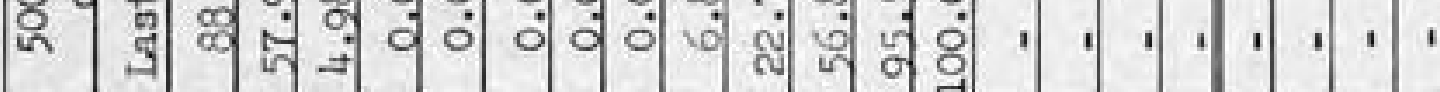

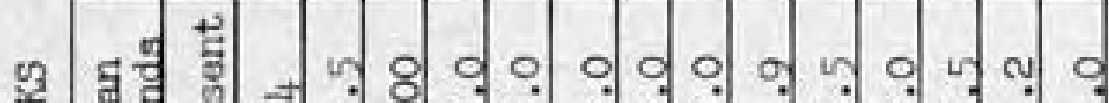

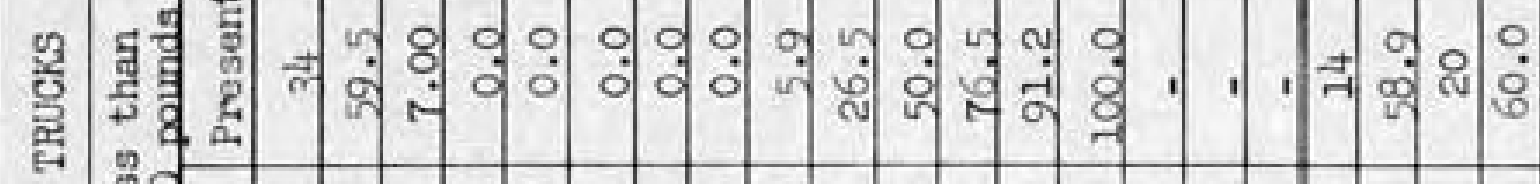

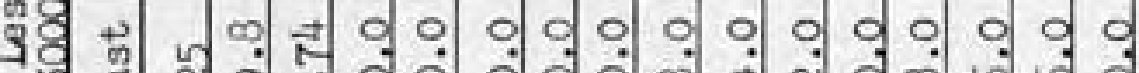

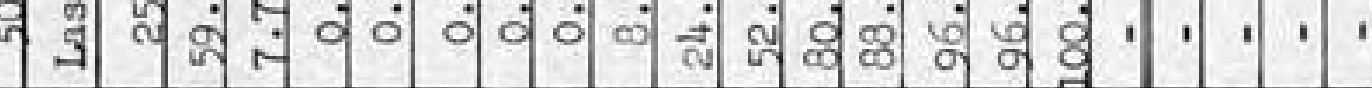

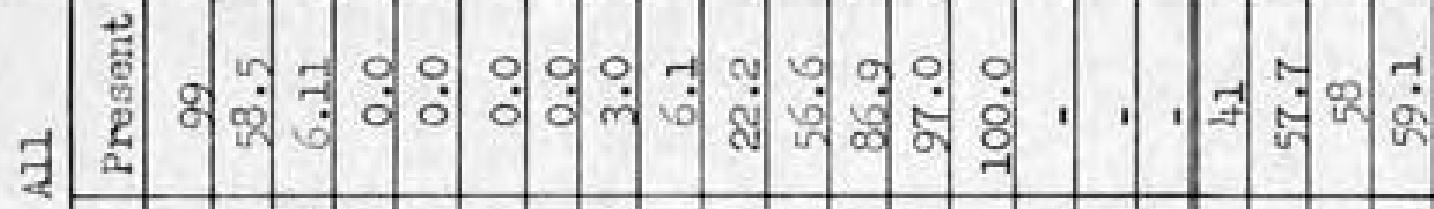

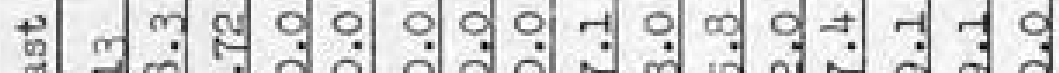

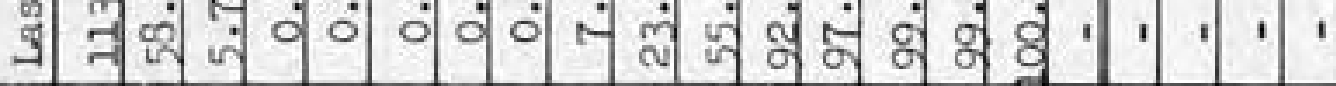

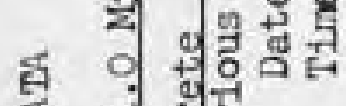

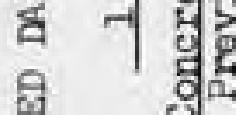

क है

1 is

9 .

悬| 量

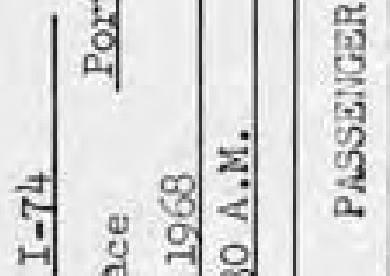

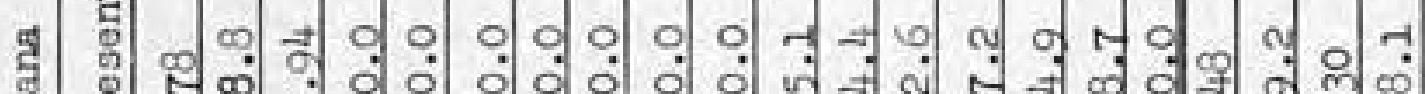

दु क्षे

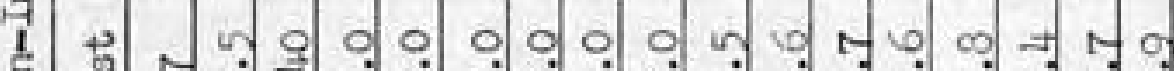

¿ 5 क

है

द्वै त्र

नु -

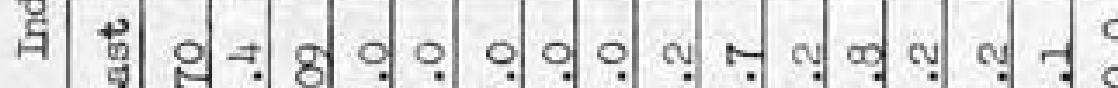

ક न

मे

का ला

당 영

$\Rightarrow$ 舲

म 5

क्ष

역 8 है

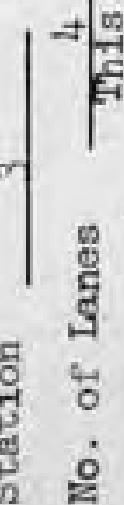

각.

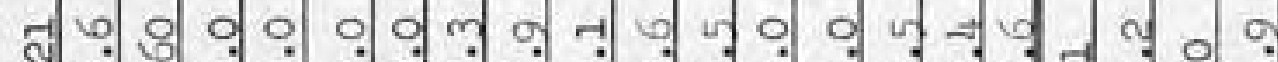

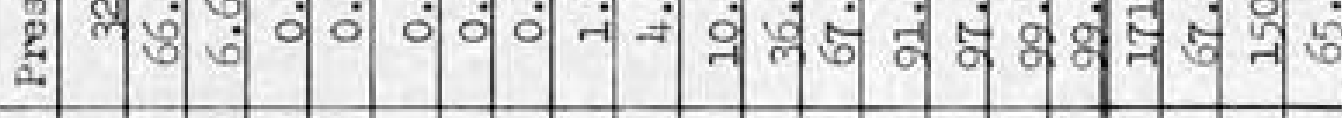

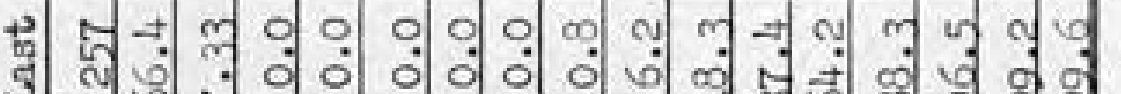

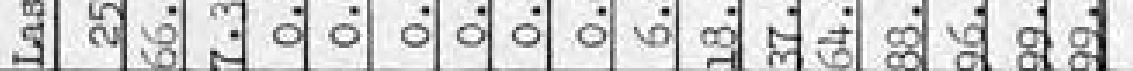

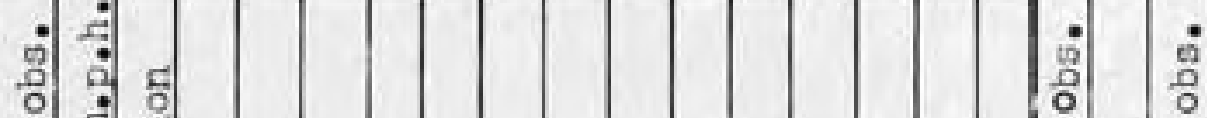

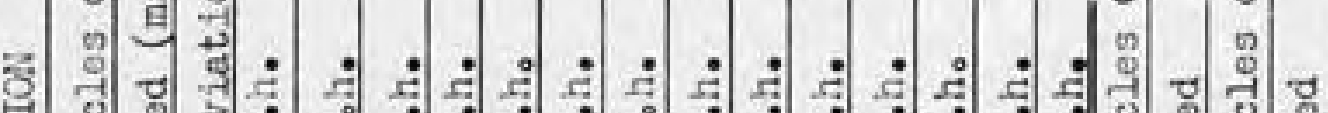

光

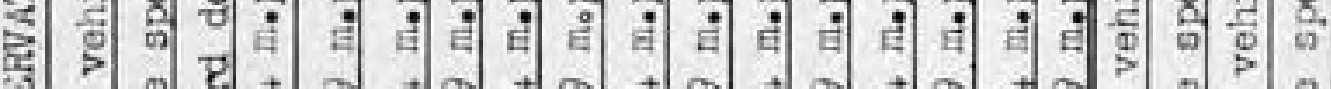

兽 क्ष

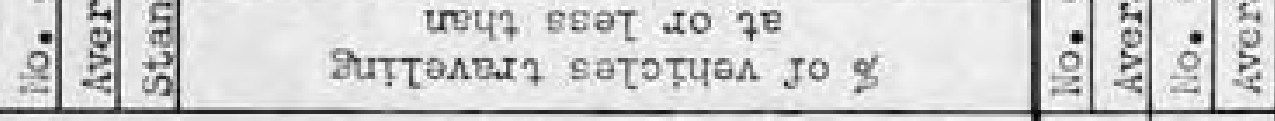


|

4

용

- 5

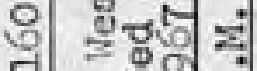

的 ज

(i) न

형 형 형

일현

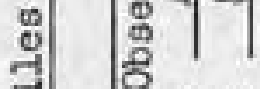

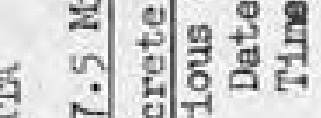

है - पै

잉

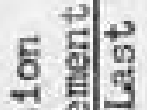

迥

+ \&

뎝 형

또

$g=$

(1)

1.

다영

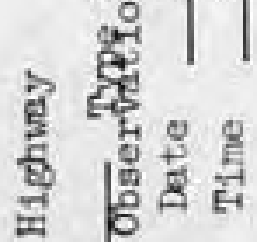

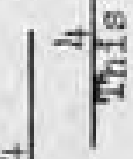

c5

婴

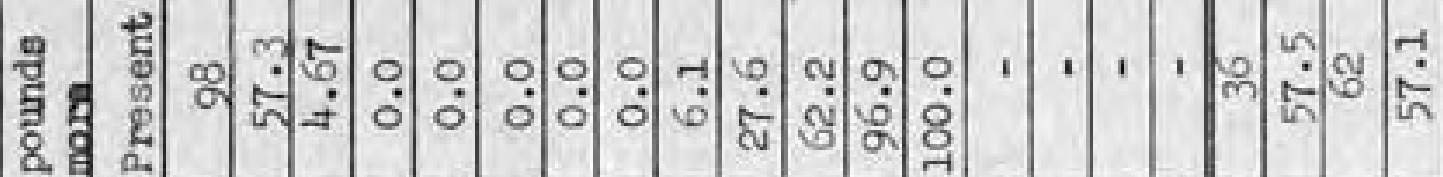

8 岁

క뎔 쳥

ฯ

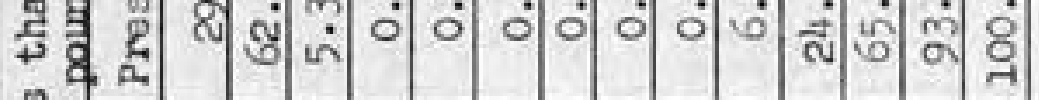

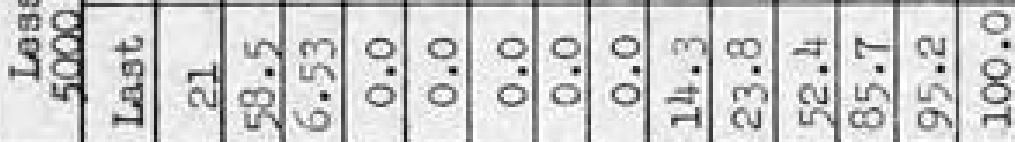

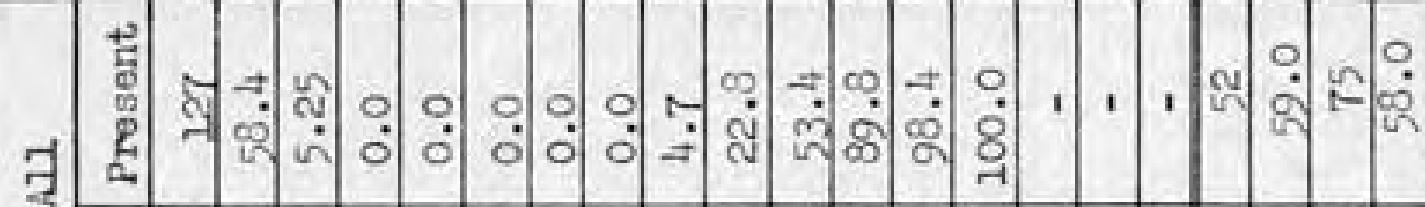

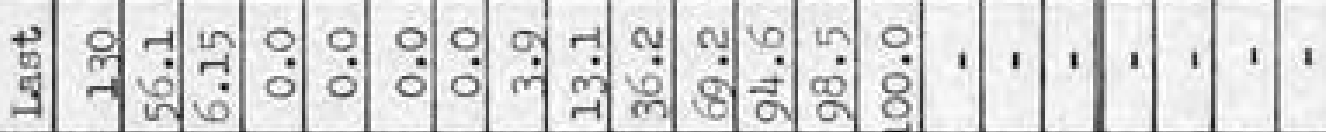

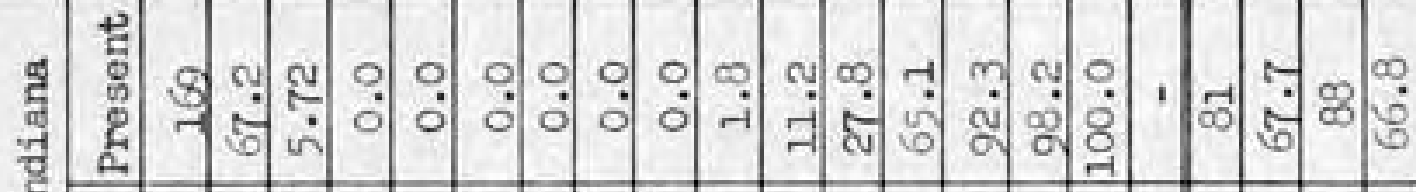

占 है ल

ऽ

击

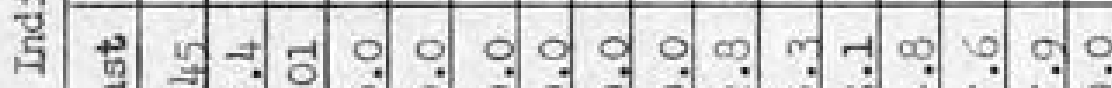

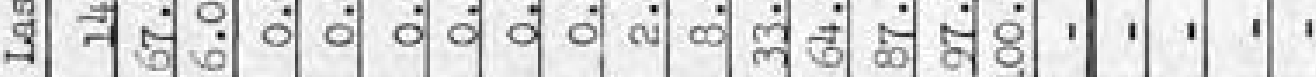

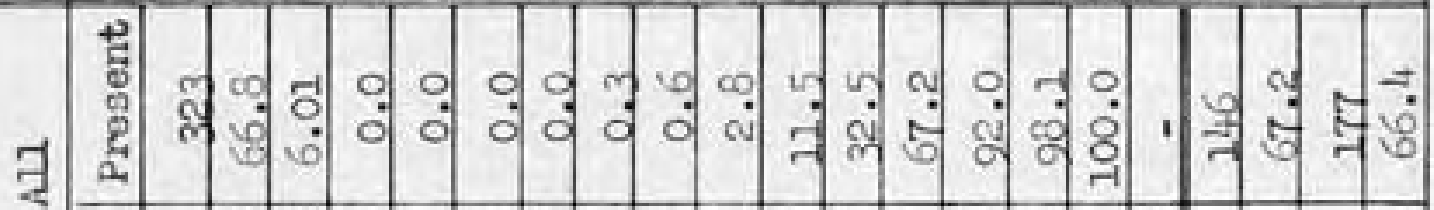

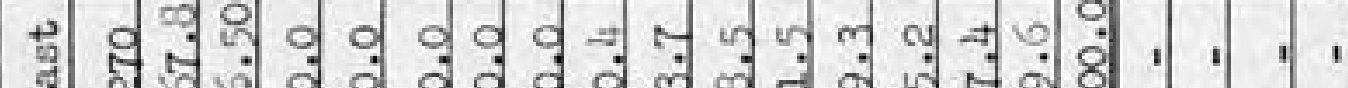

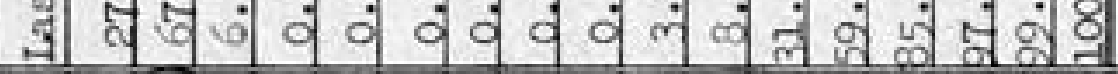

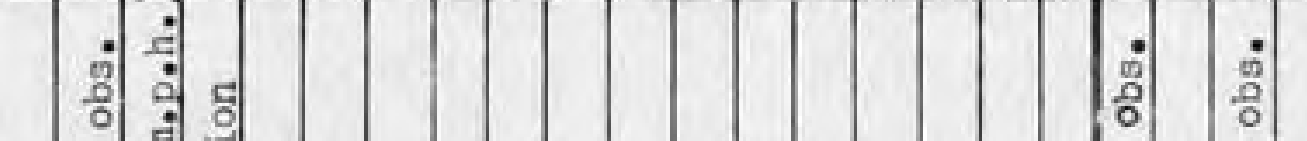

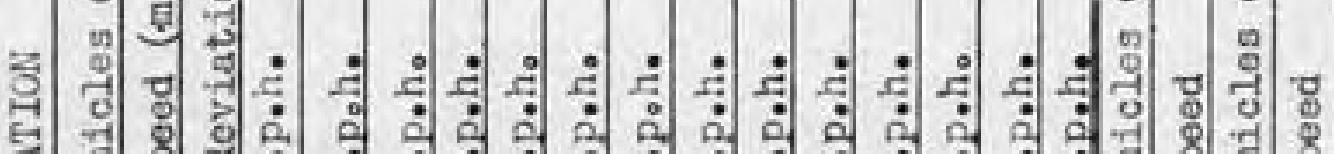

求

票

ㅇำ कै 
| क्जी

t

$4 \frac{1}{8}$

$\infty$

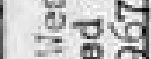

두 $\Phi$ 궁

( )

जा वे

돌 불

(2) द्व

a)

7 .

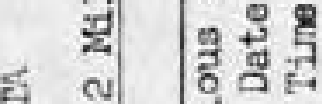

ह -1 窟

+

.

की

가 800

量

E

ल $\quad$ 궐

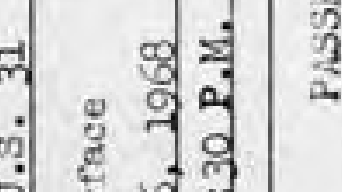

है

궁

$\Rightarrow$ है

娄 1000

$1=0$

n

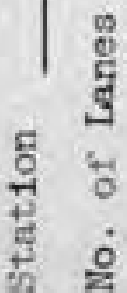

दु

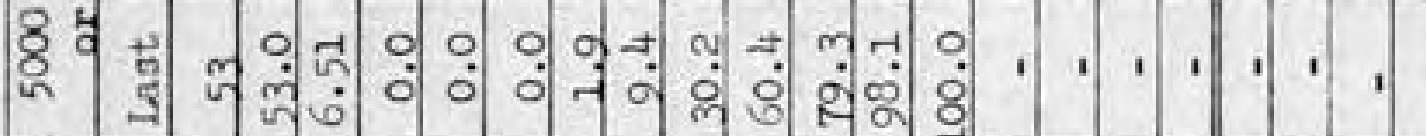

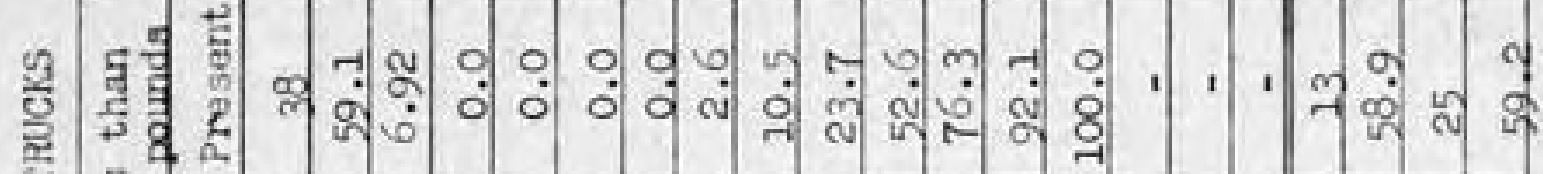

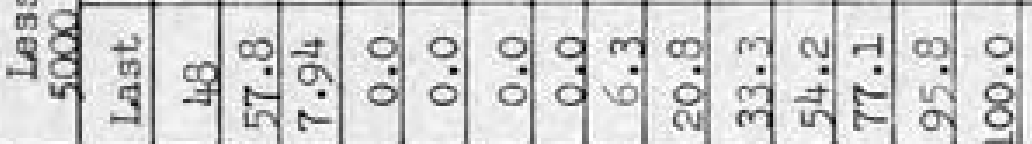

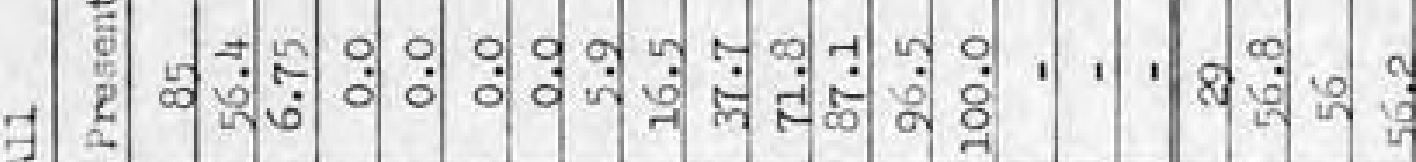

견:

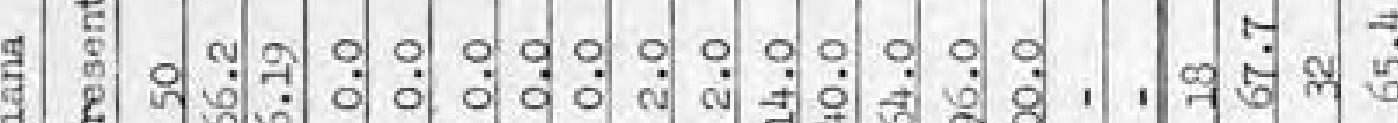

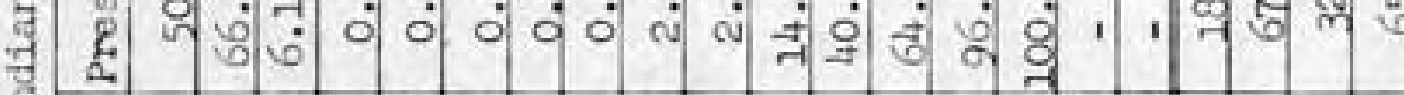

1 눈

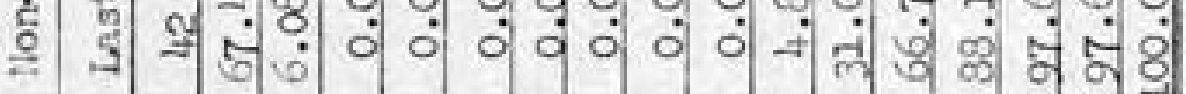

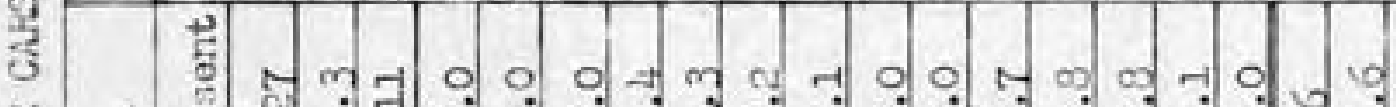

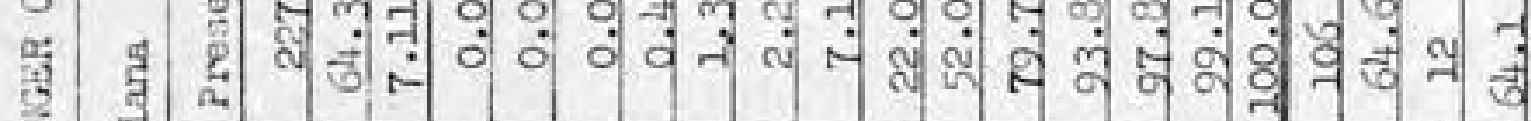

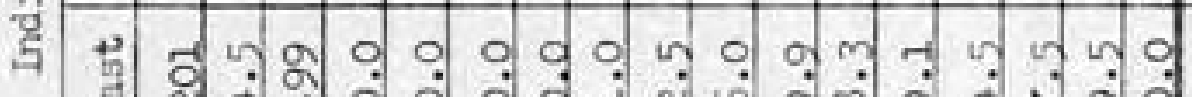

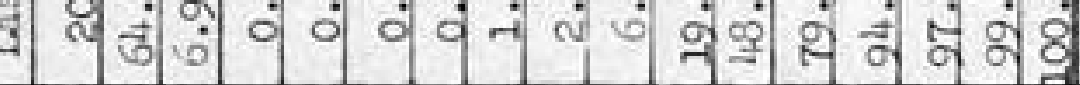

1

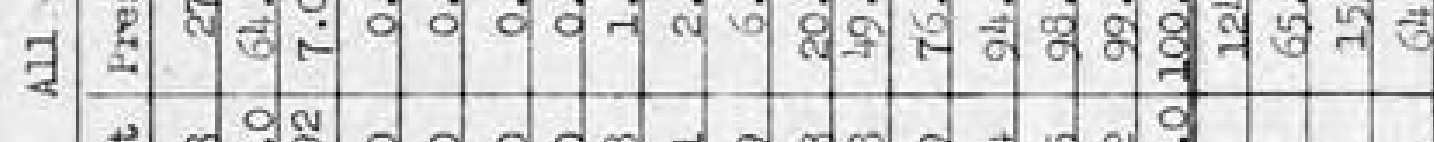

궁영 0

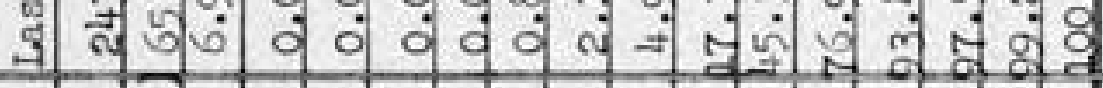

:

워 영

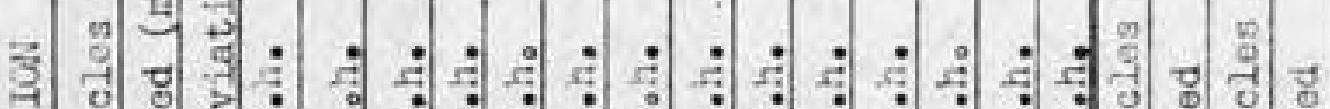

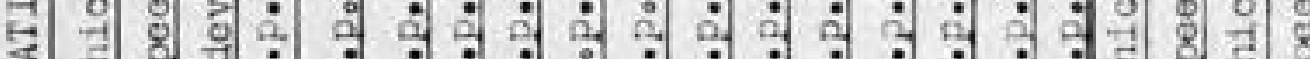

乌ํํำ

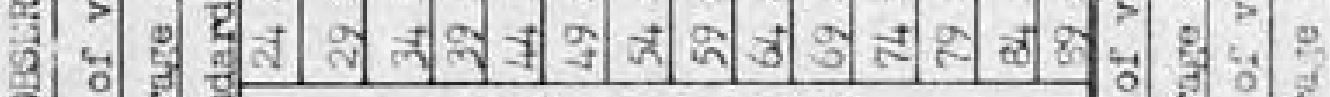

के

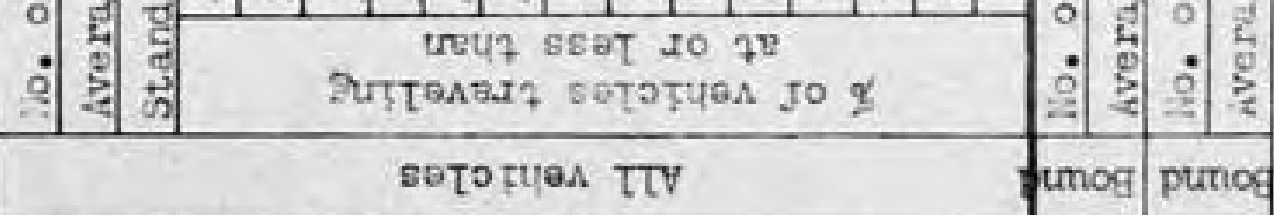


वै.

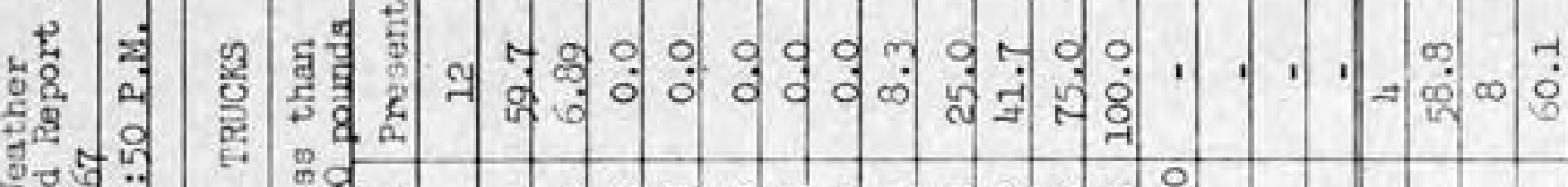
ले

a)

क)

항

15 4

+4)

o 130

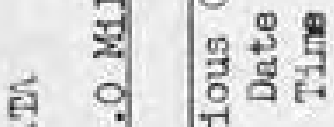

है -1

㲾

है

क)

o.

-

둥

पे

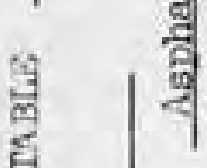

Q

जै है वैं

ते है

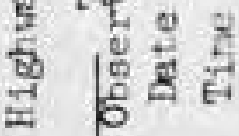

-

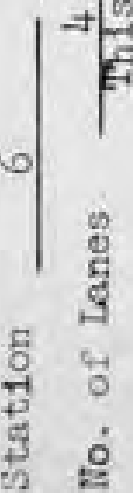

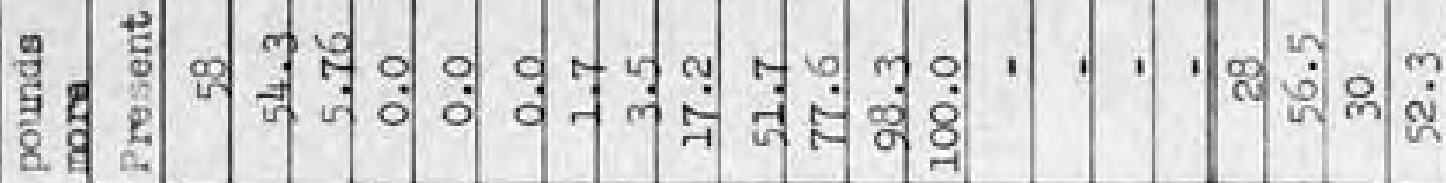

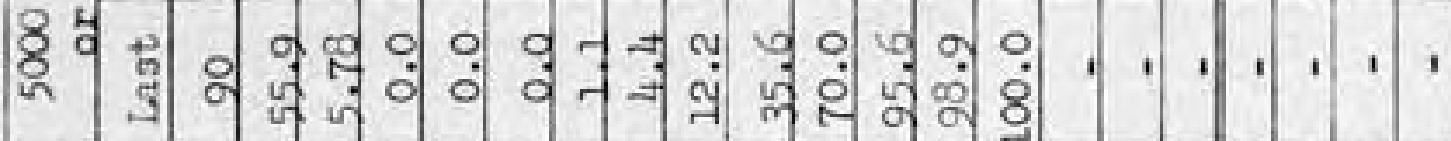




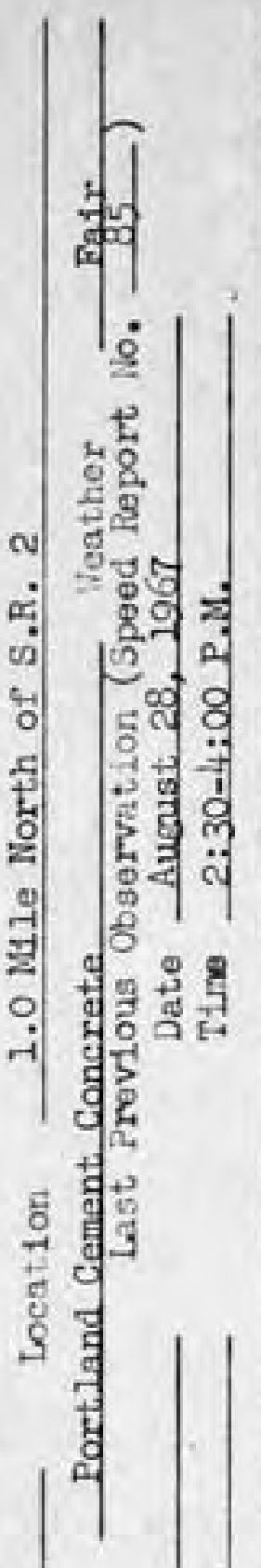

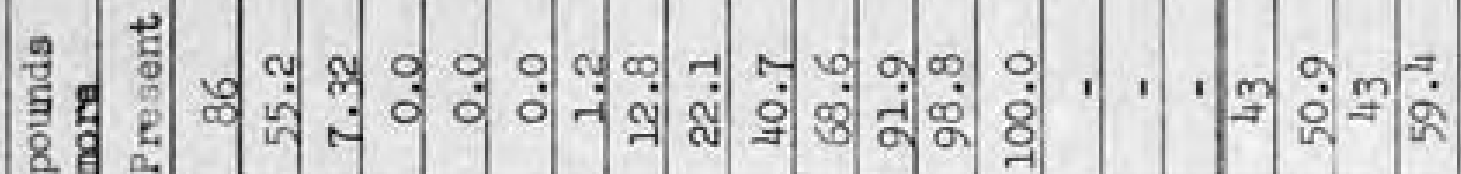

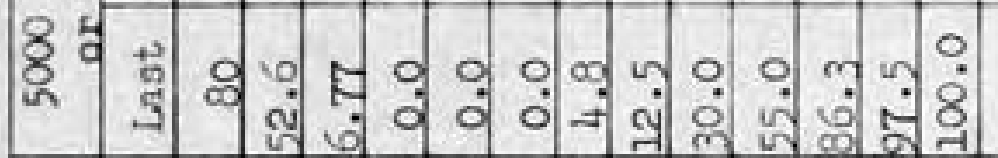

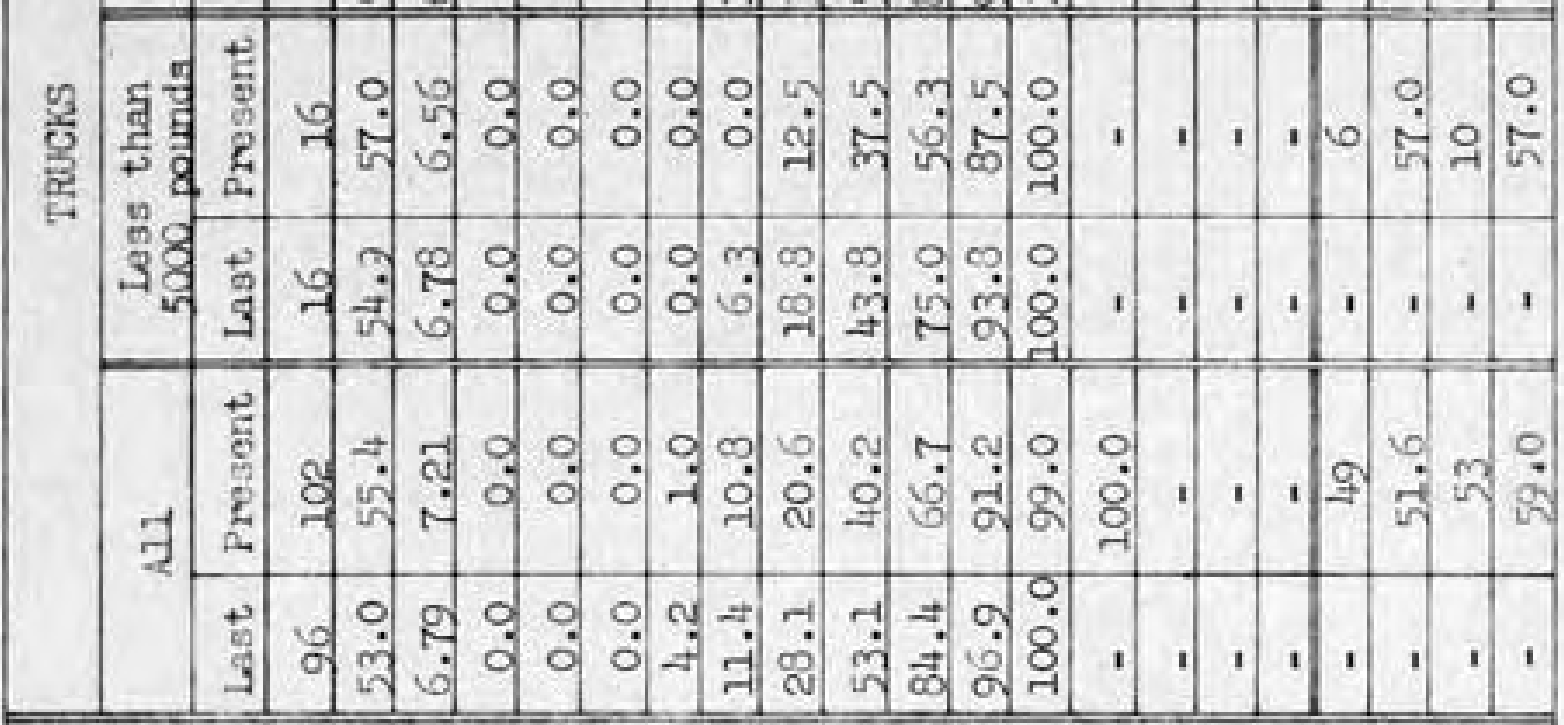

ฝึ क्षैठี

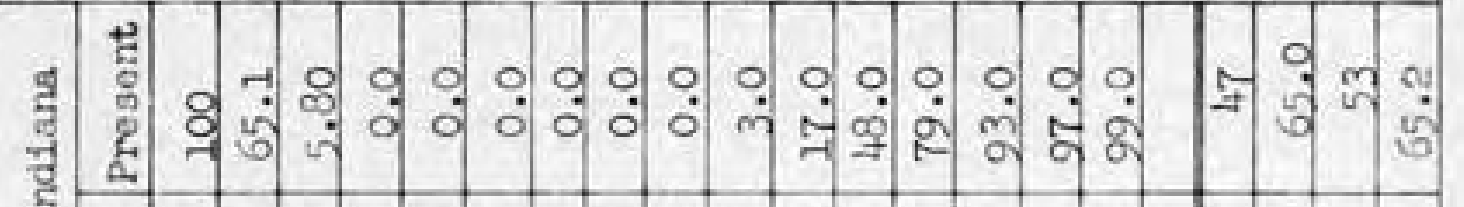

占

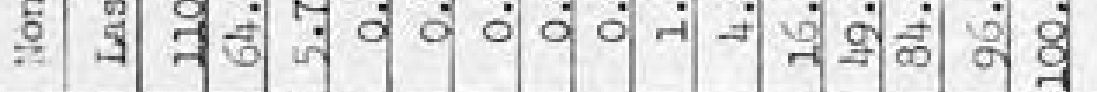

दै ₹

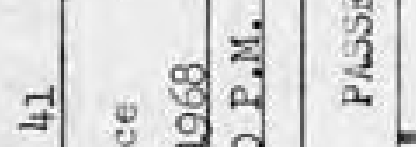

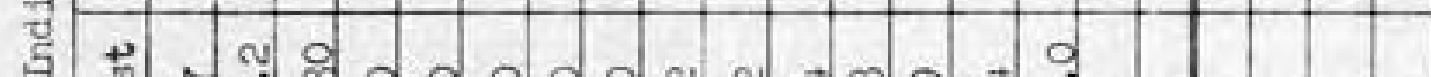

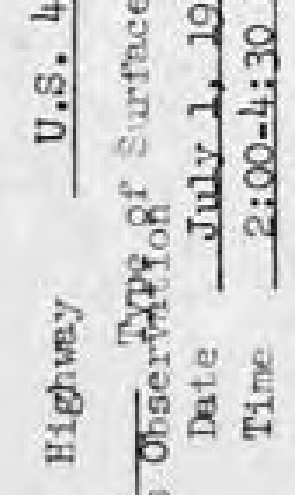

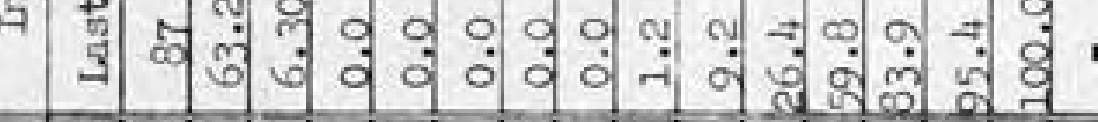

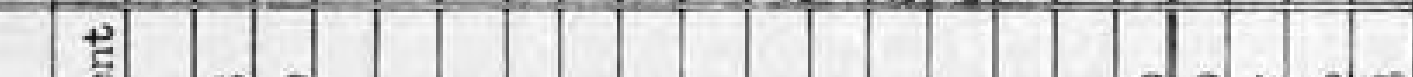

ज़

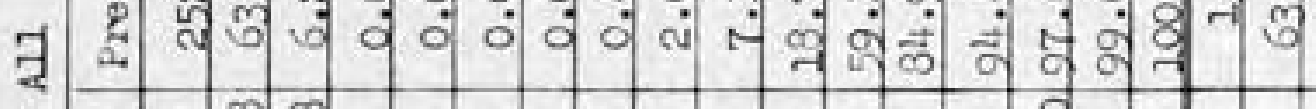

క

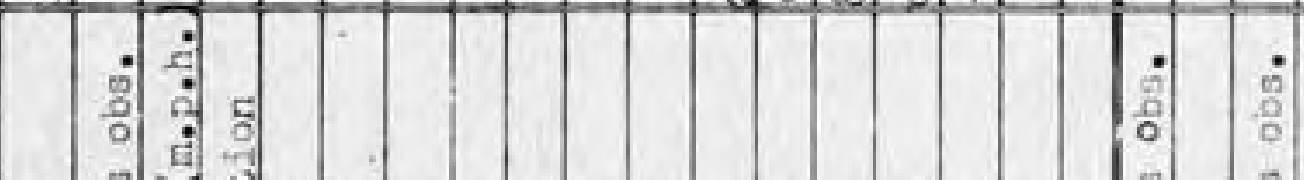

过

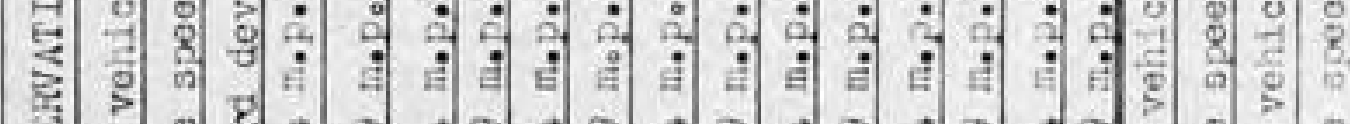

H

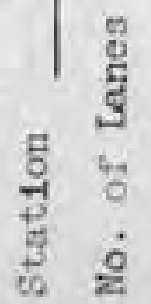

बै। 


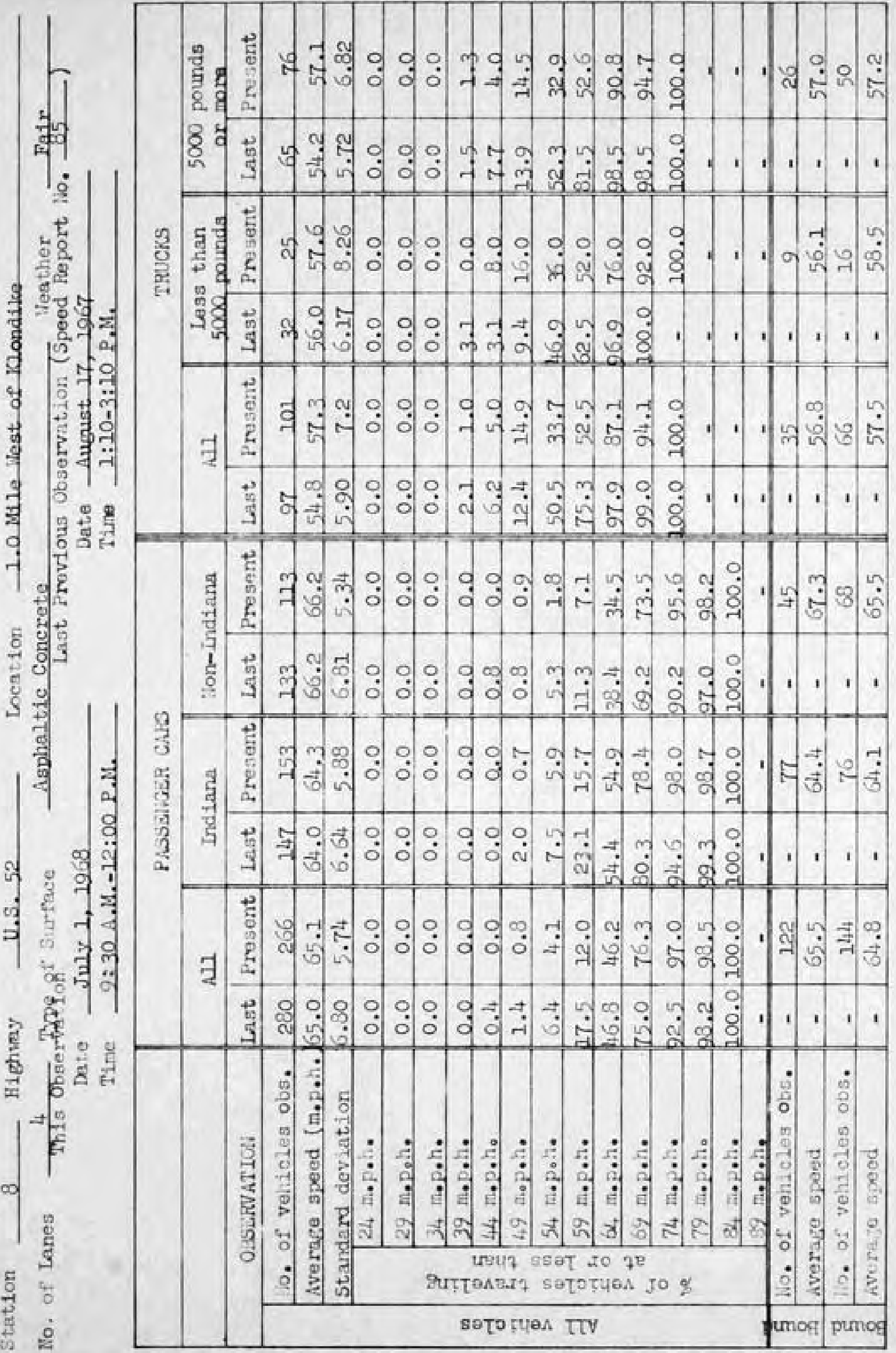




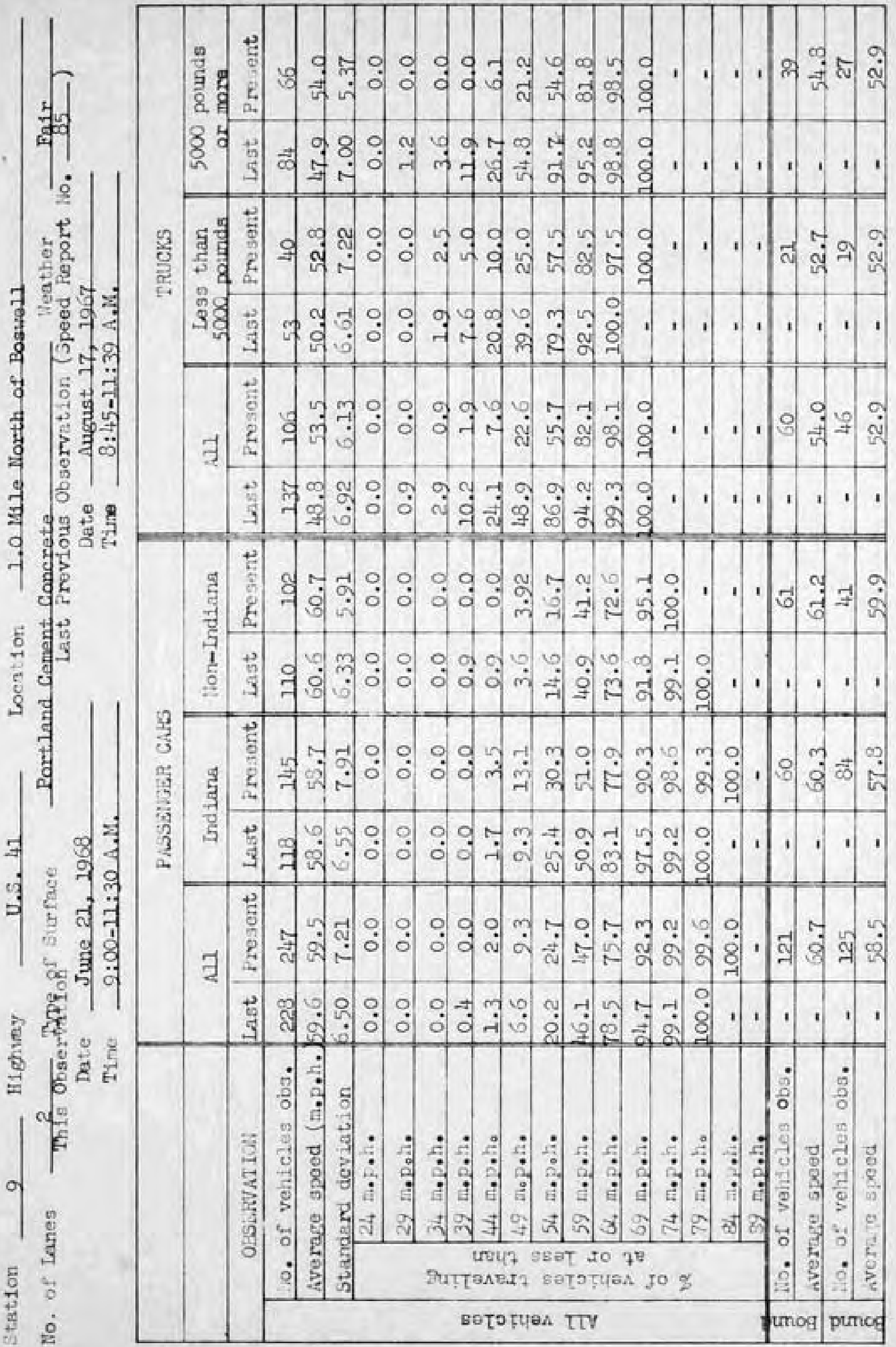




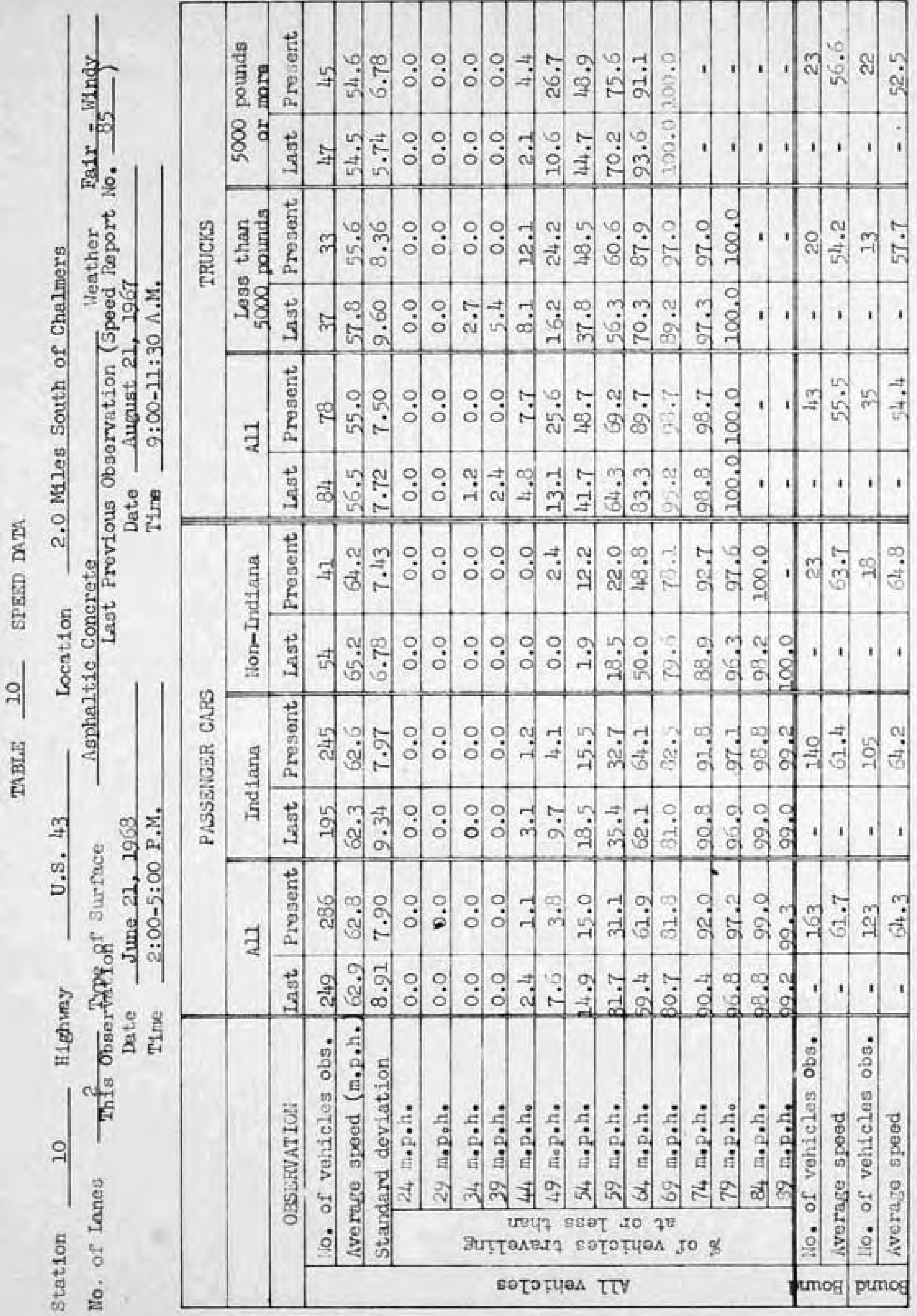




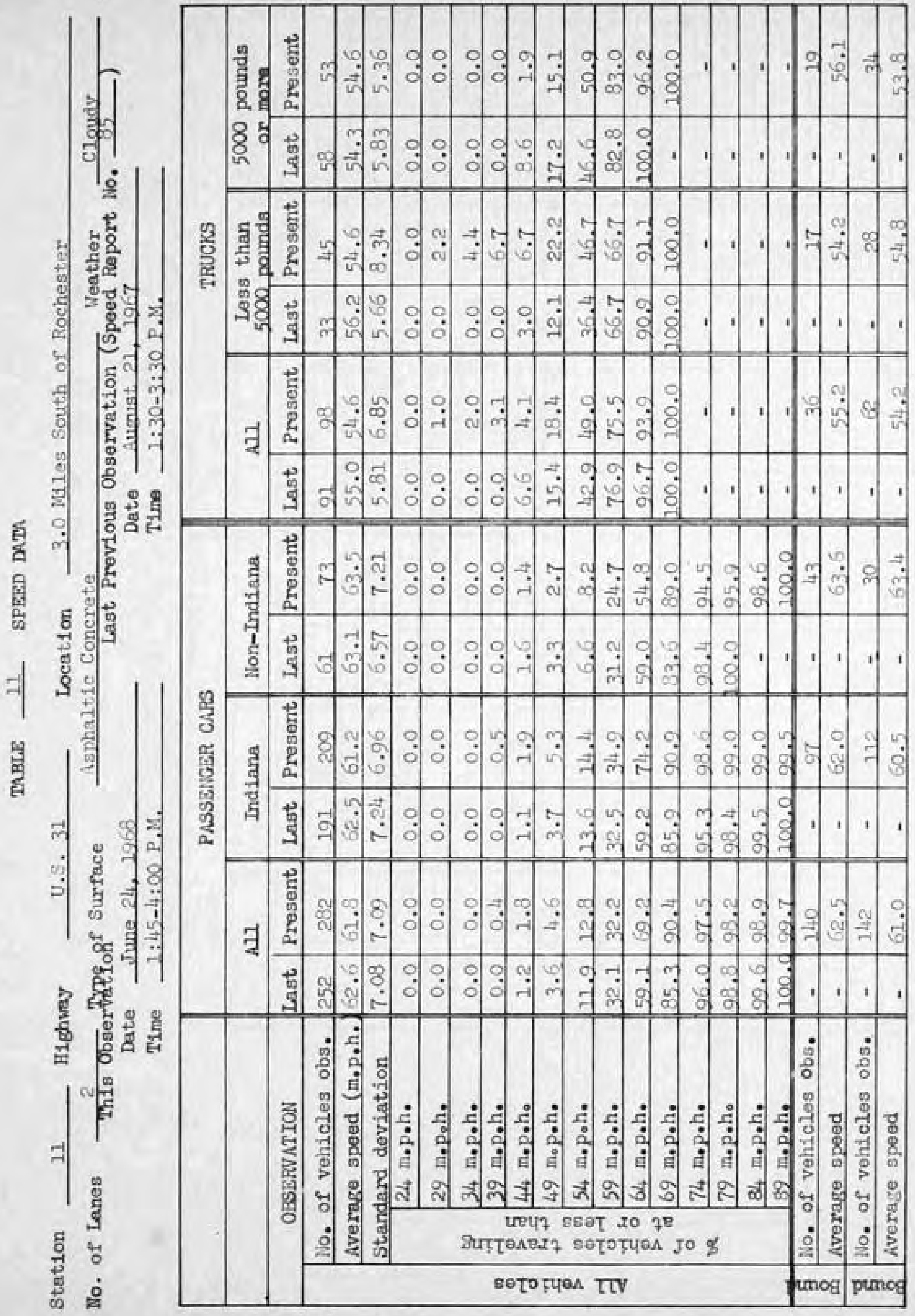




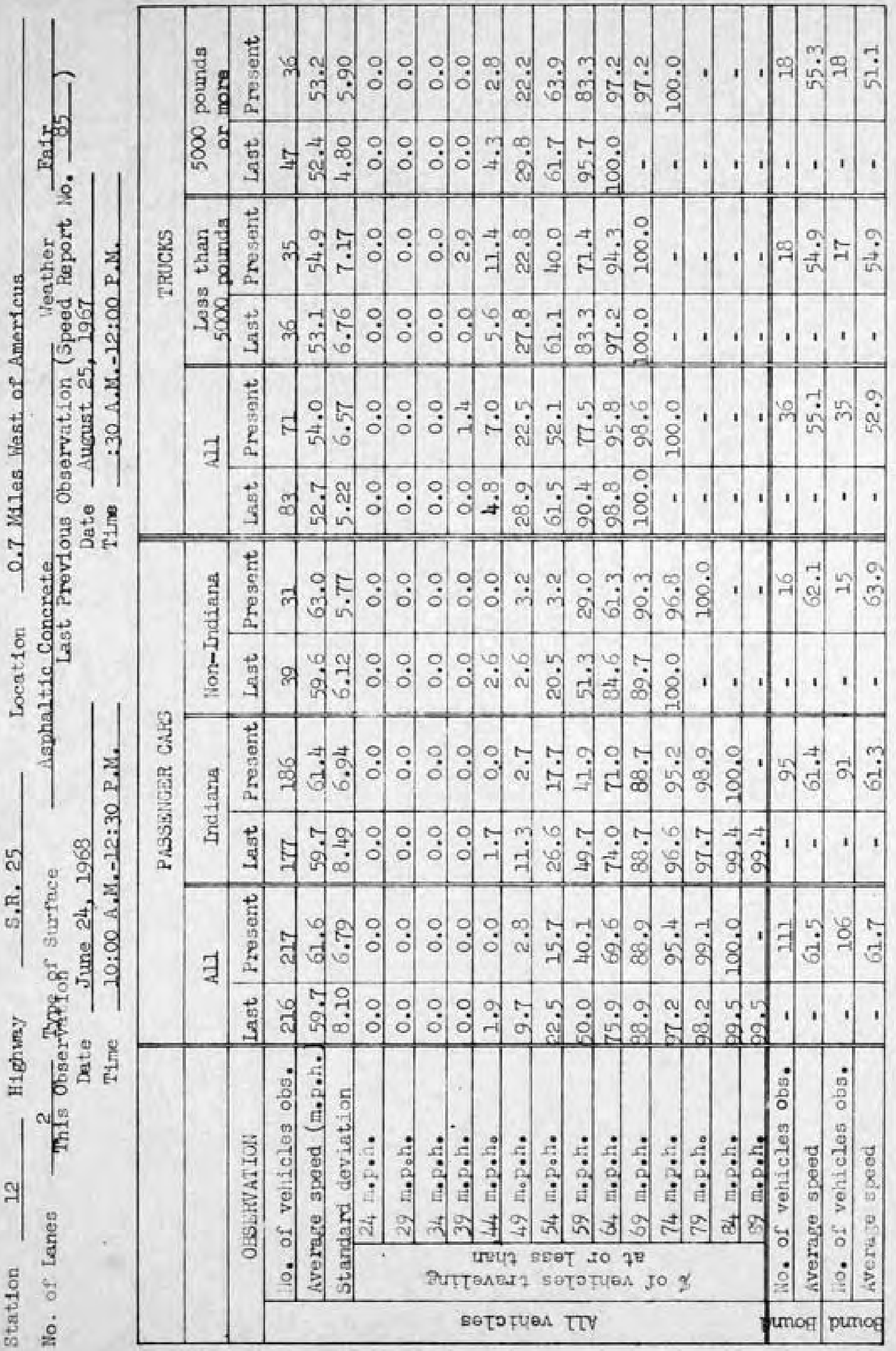




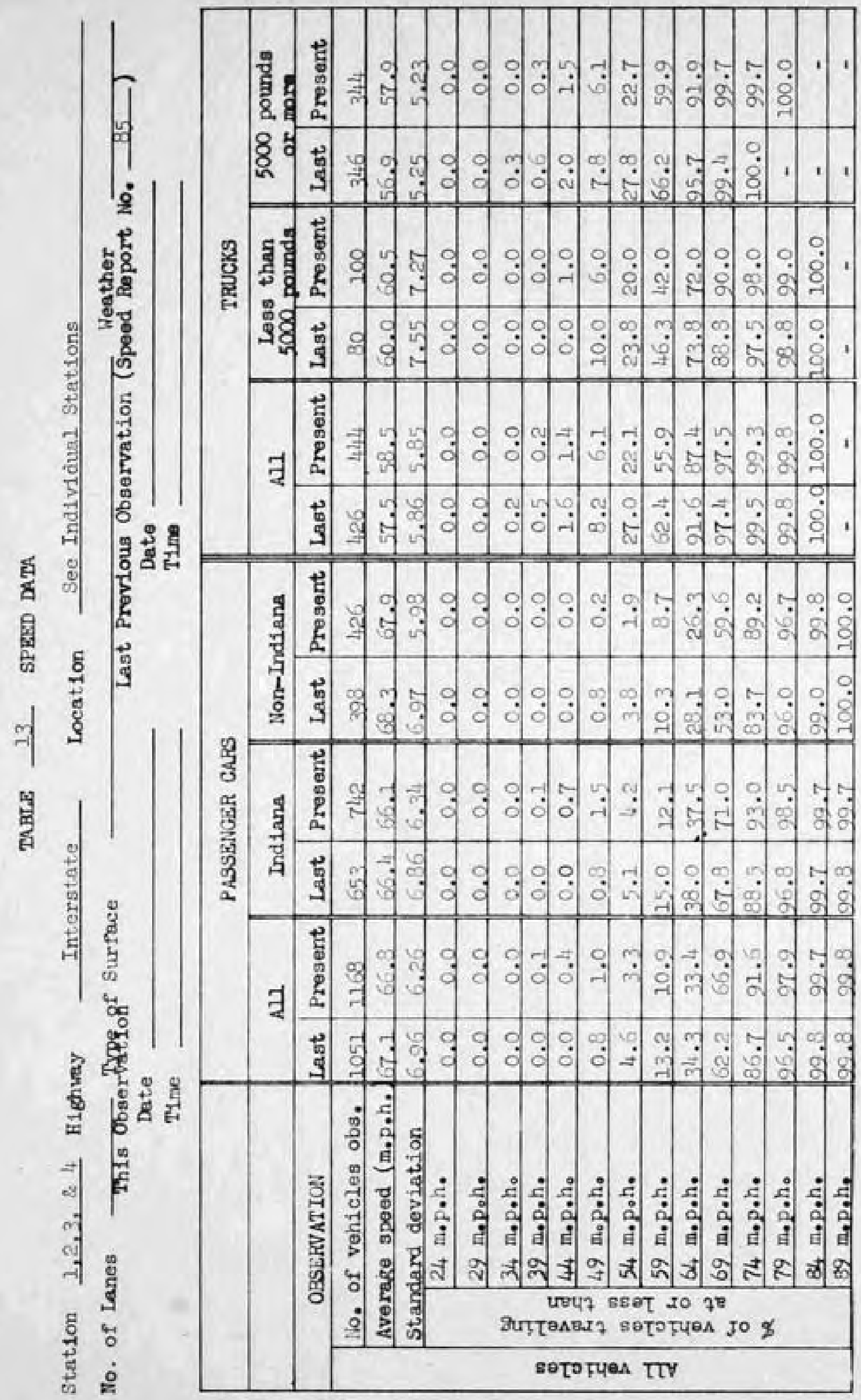




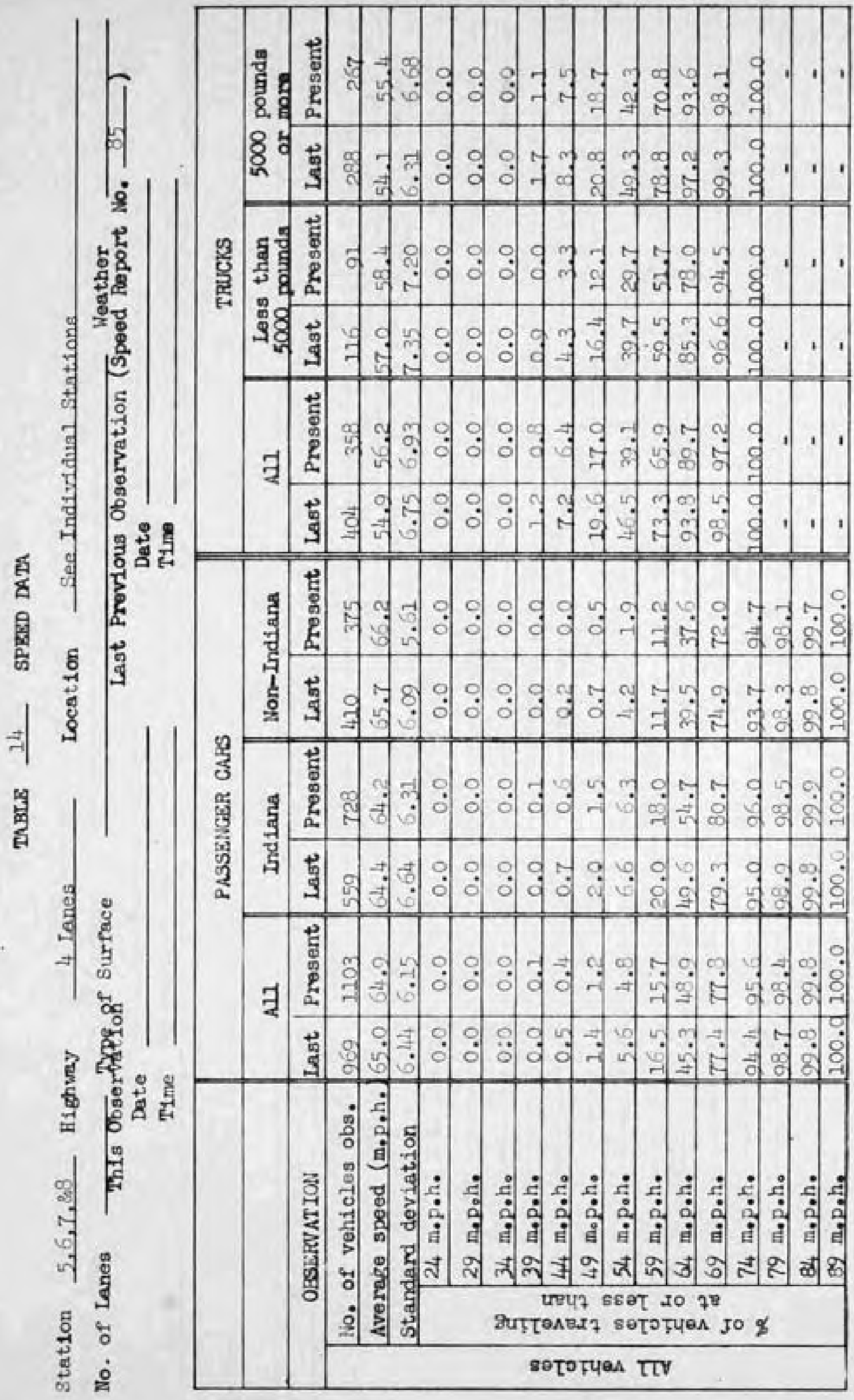




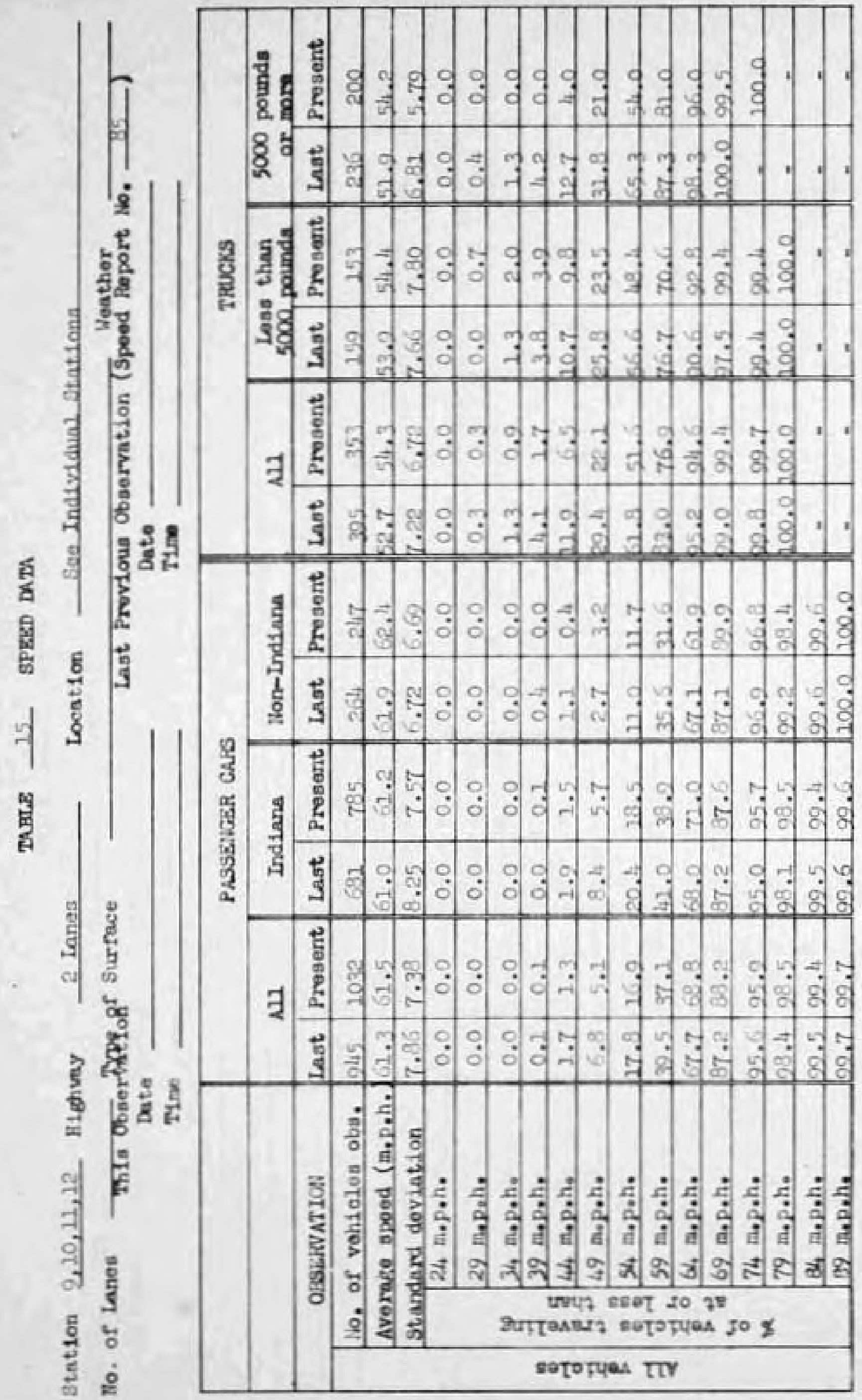




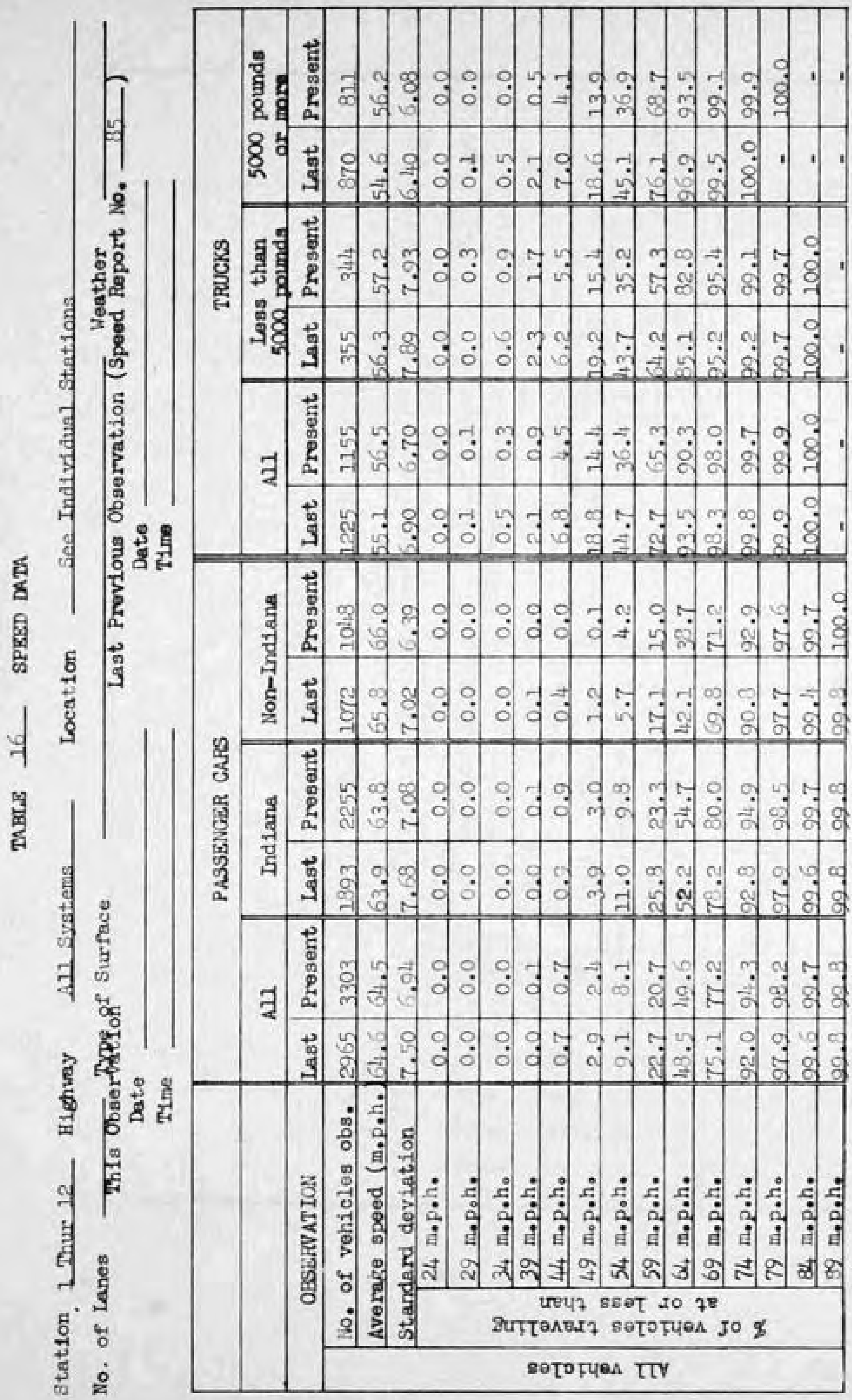




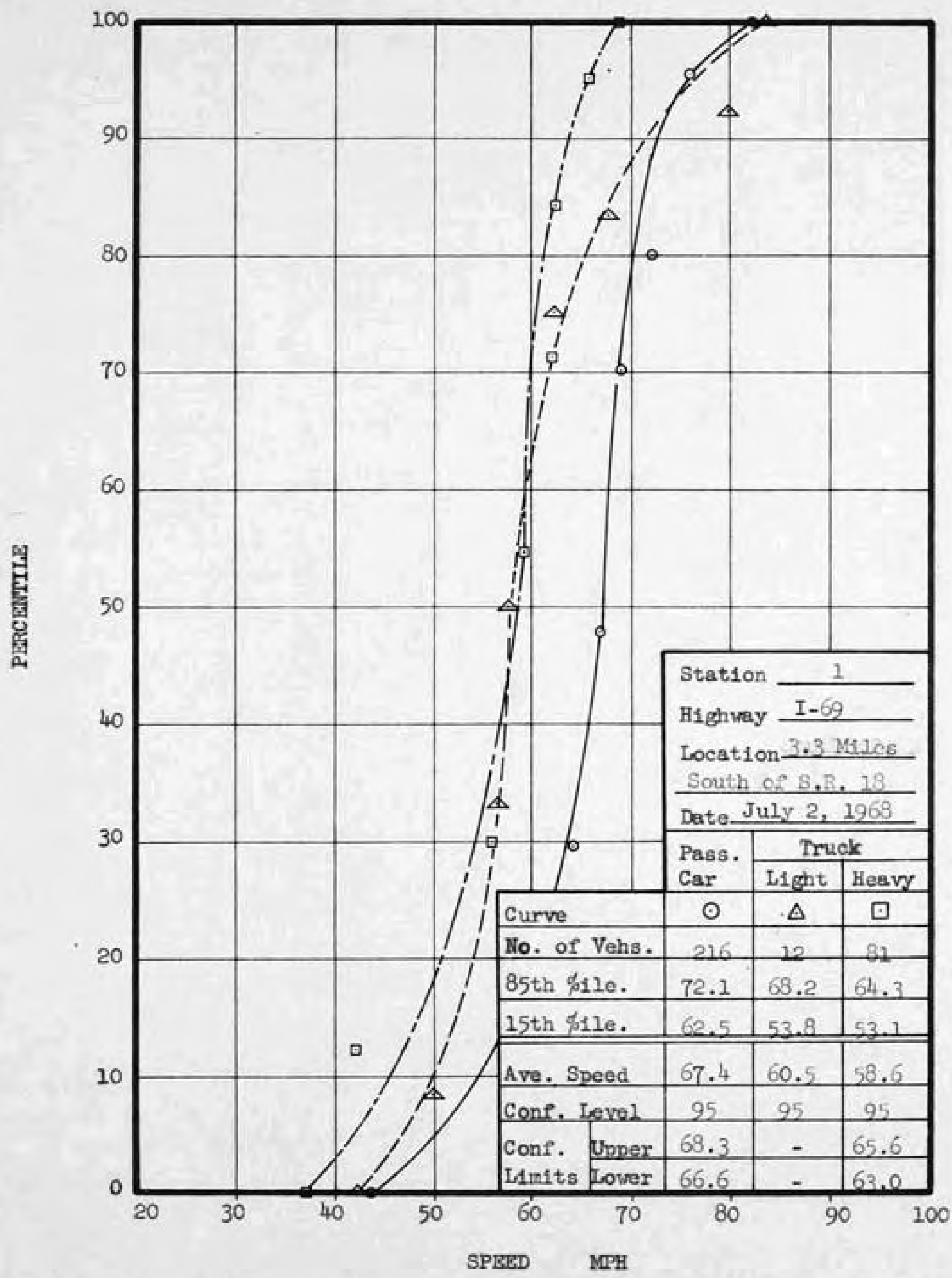




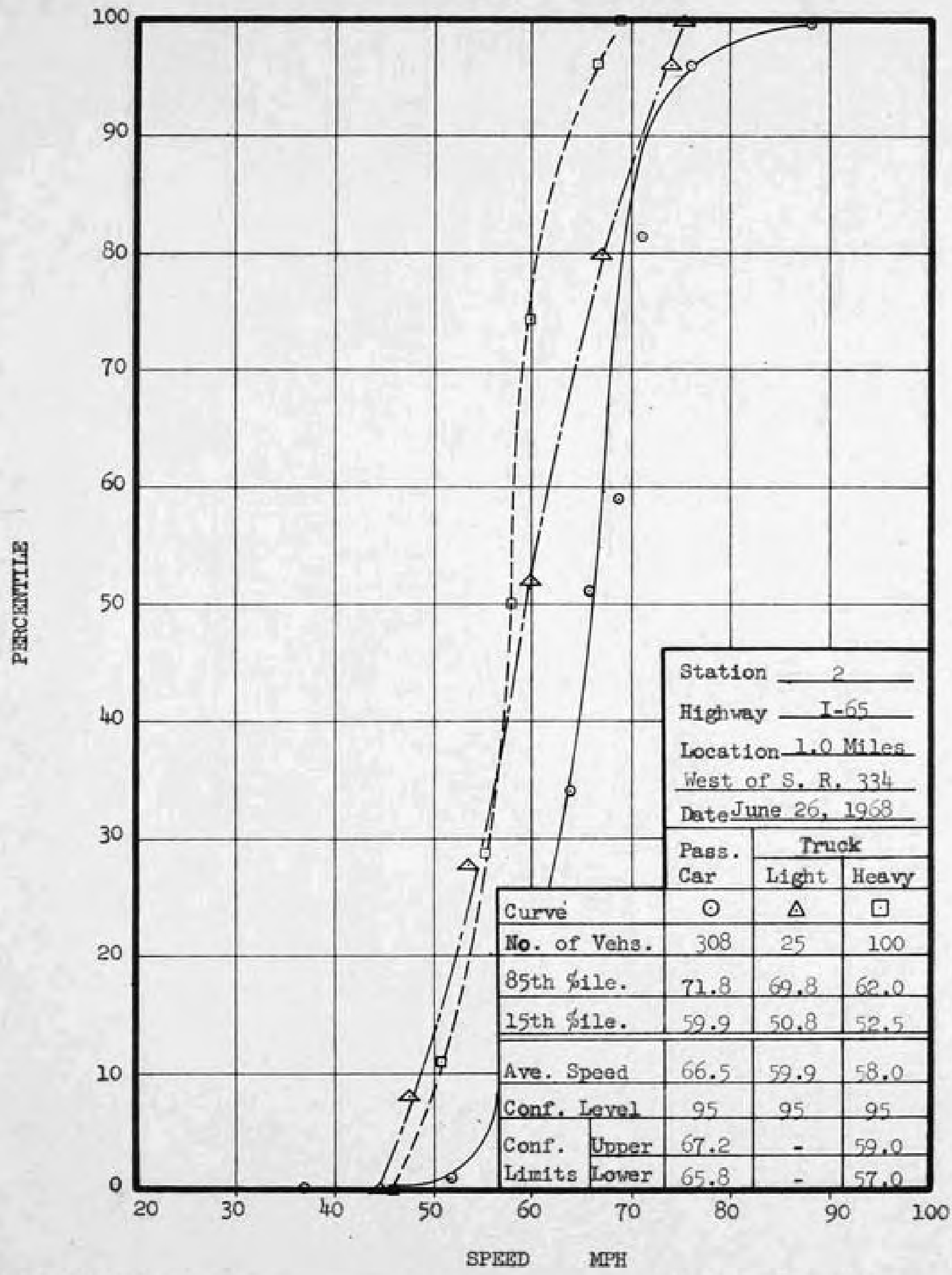




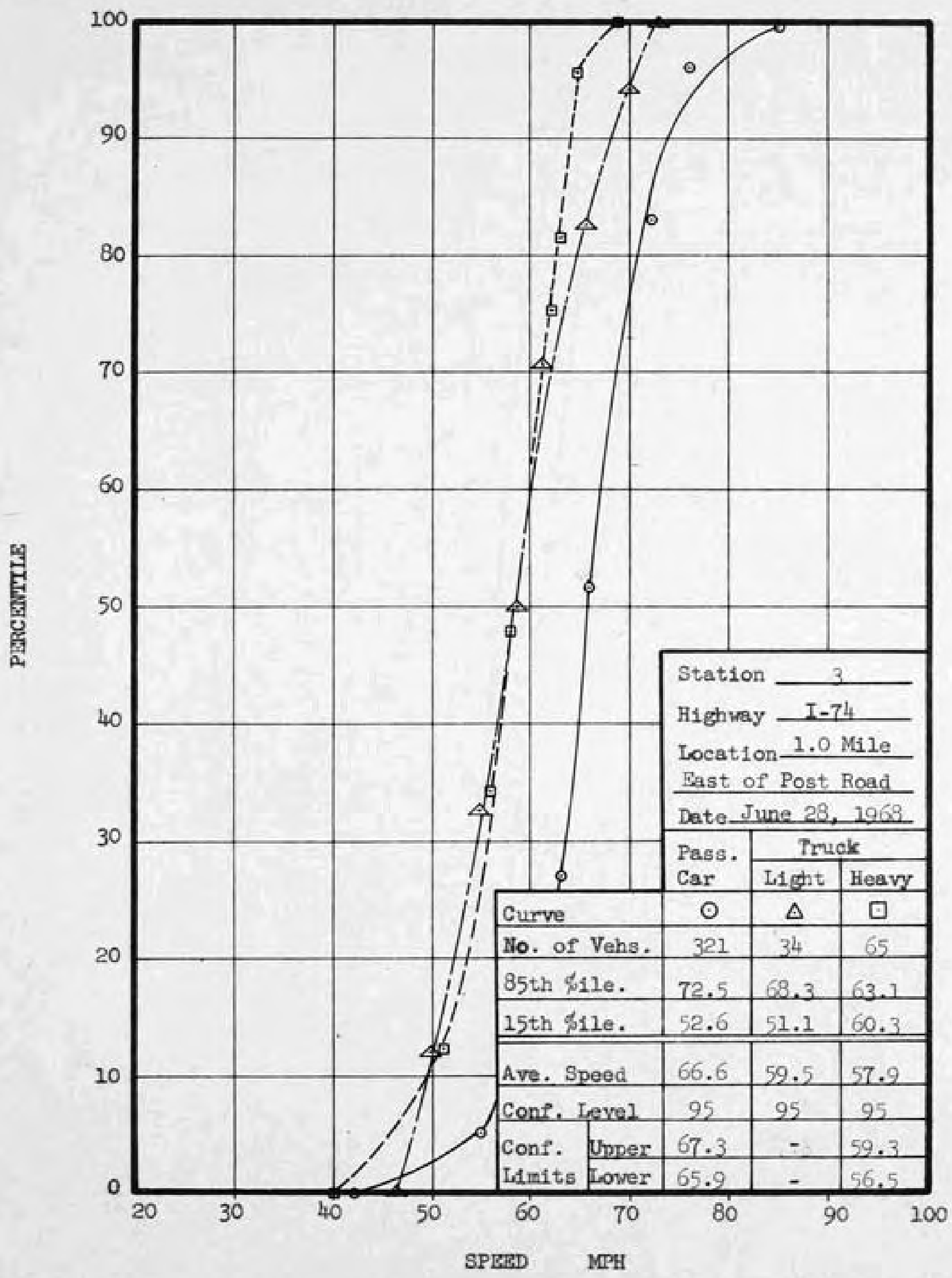




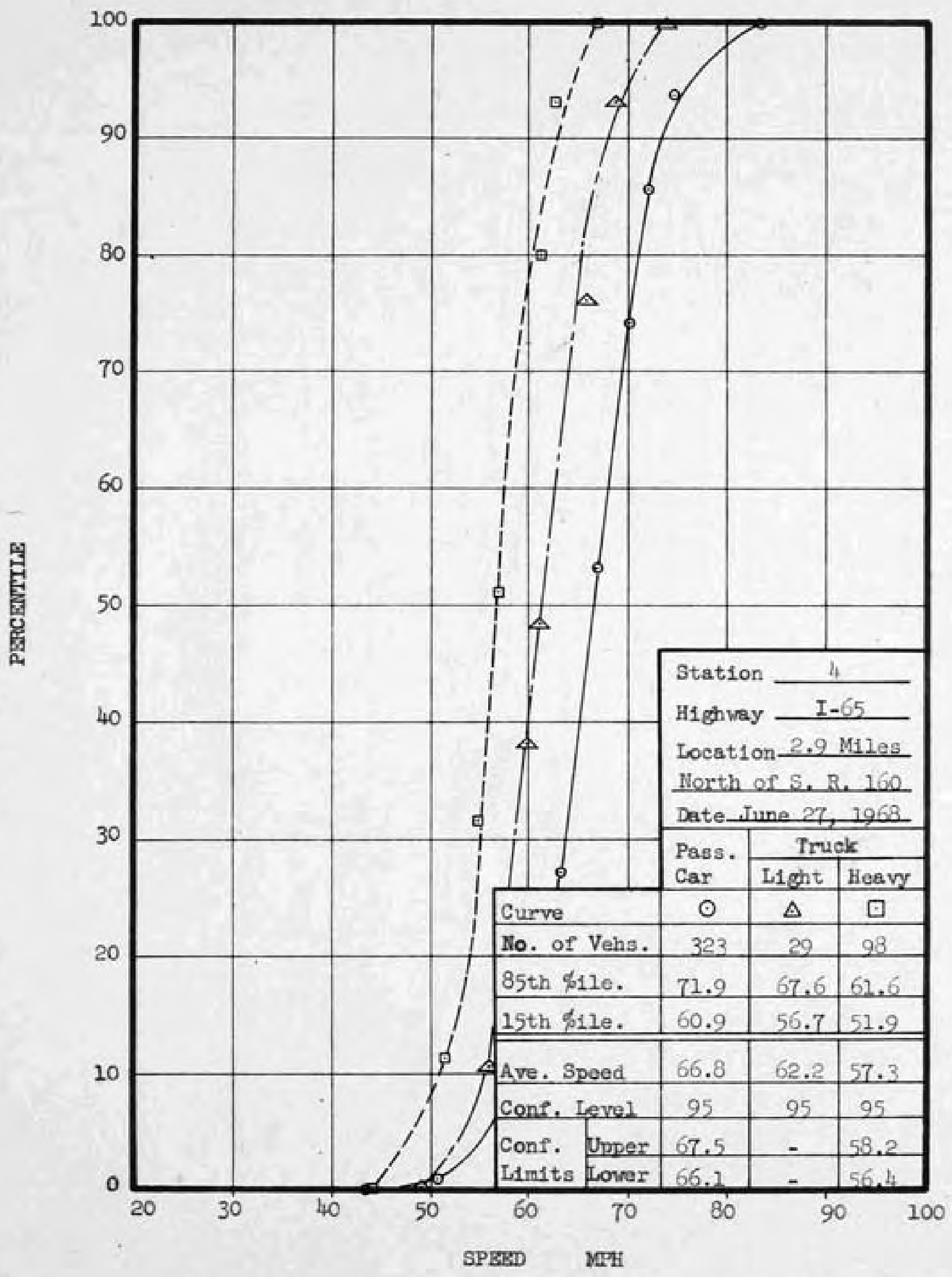




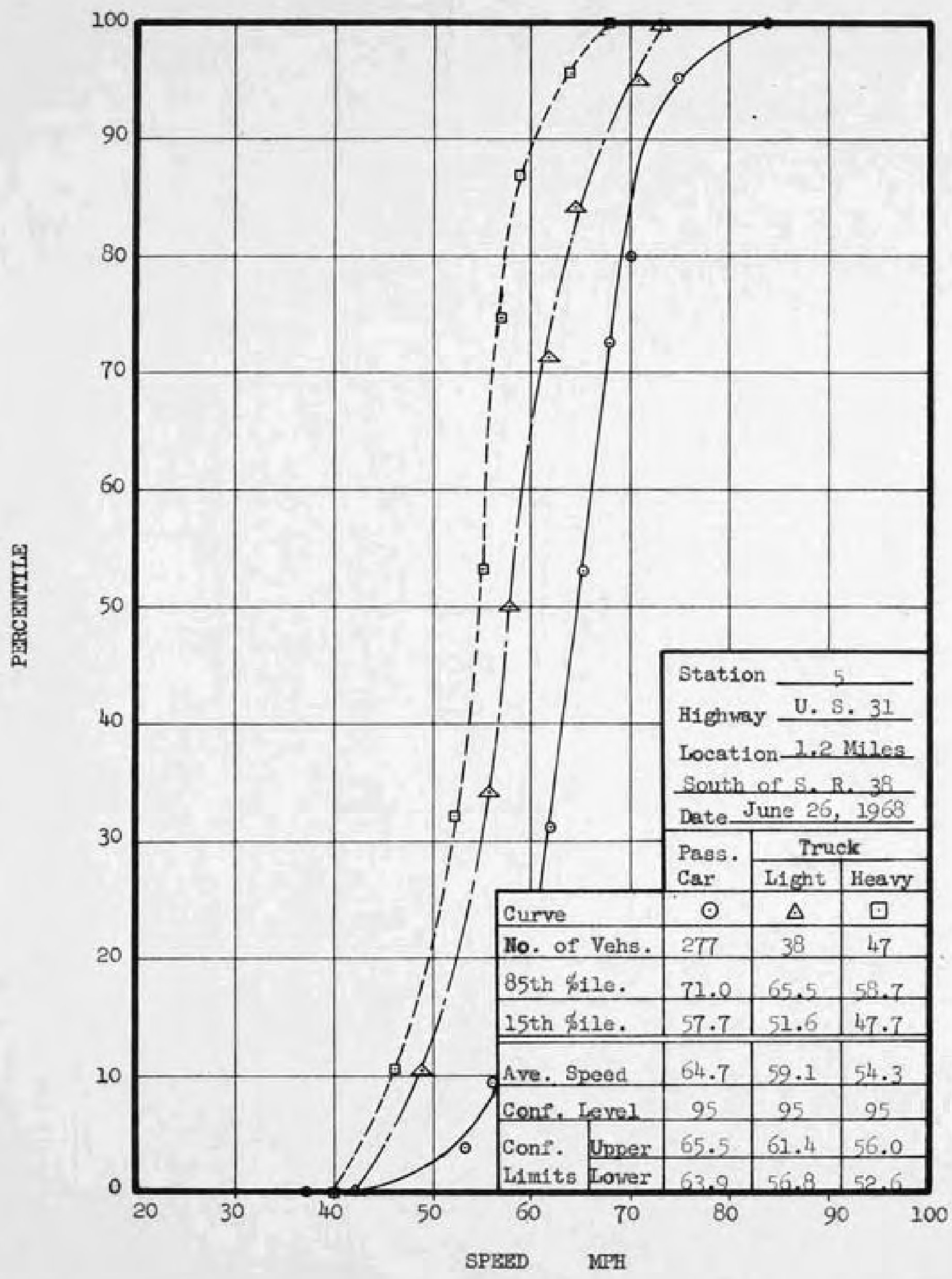




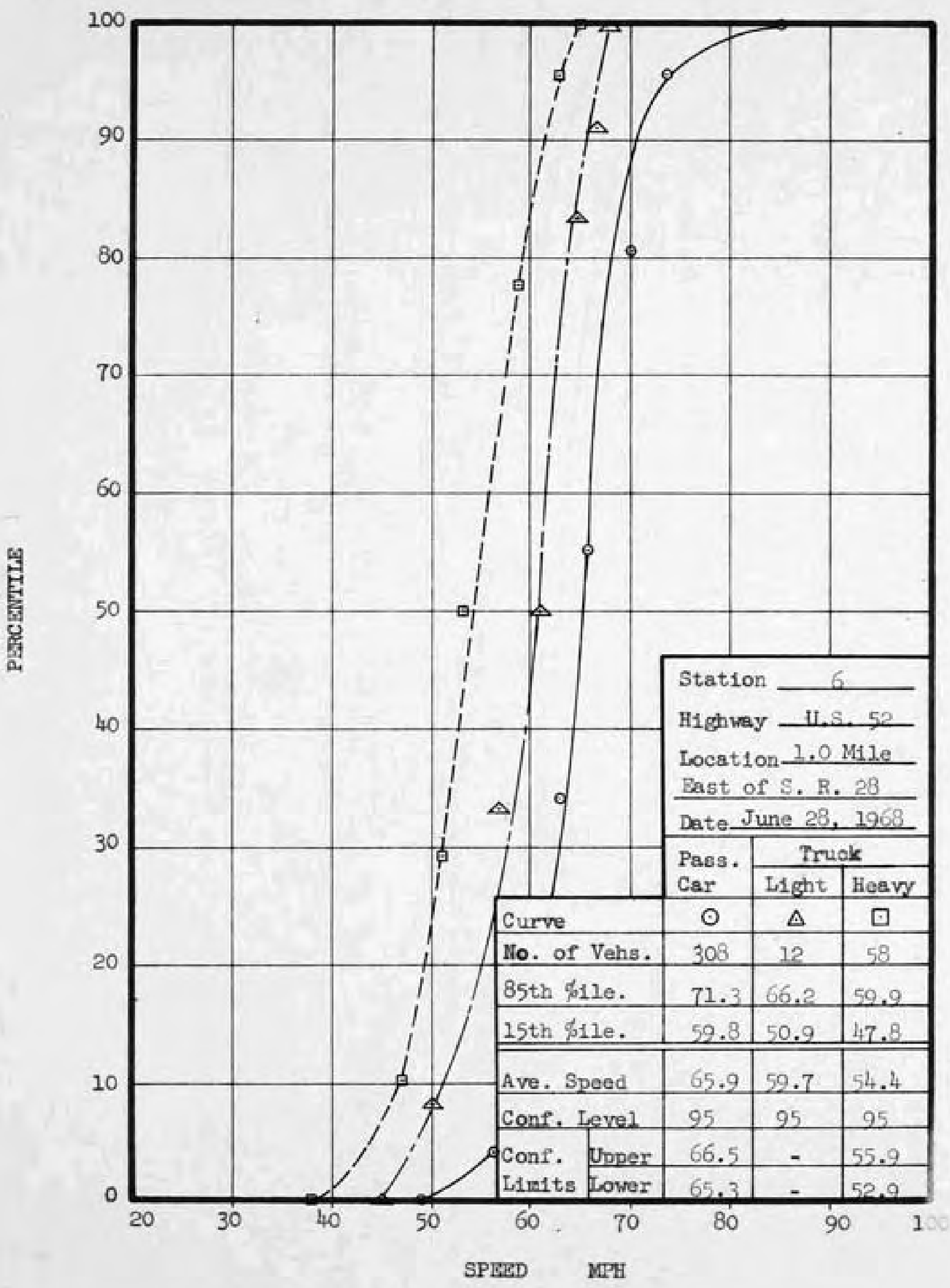




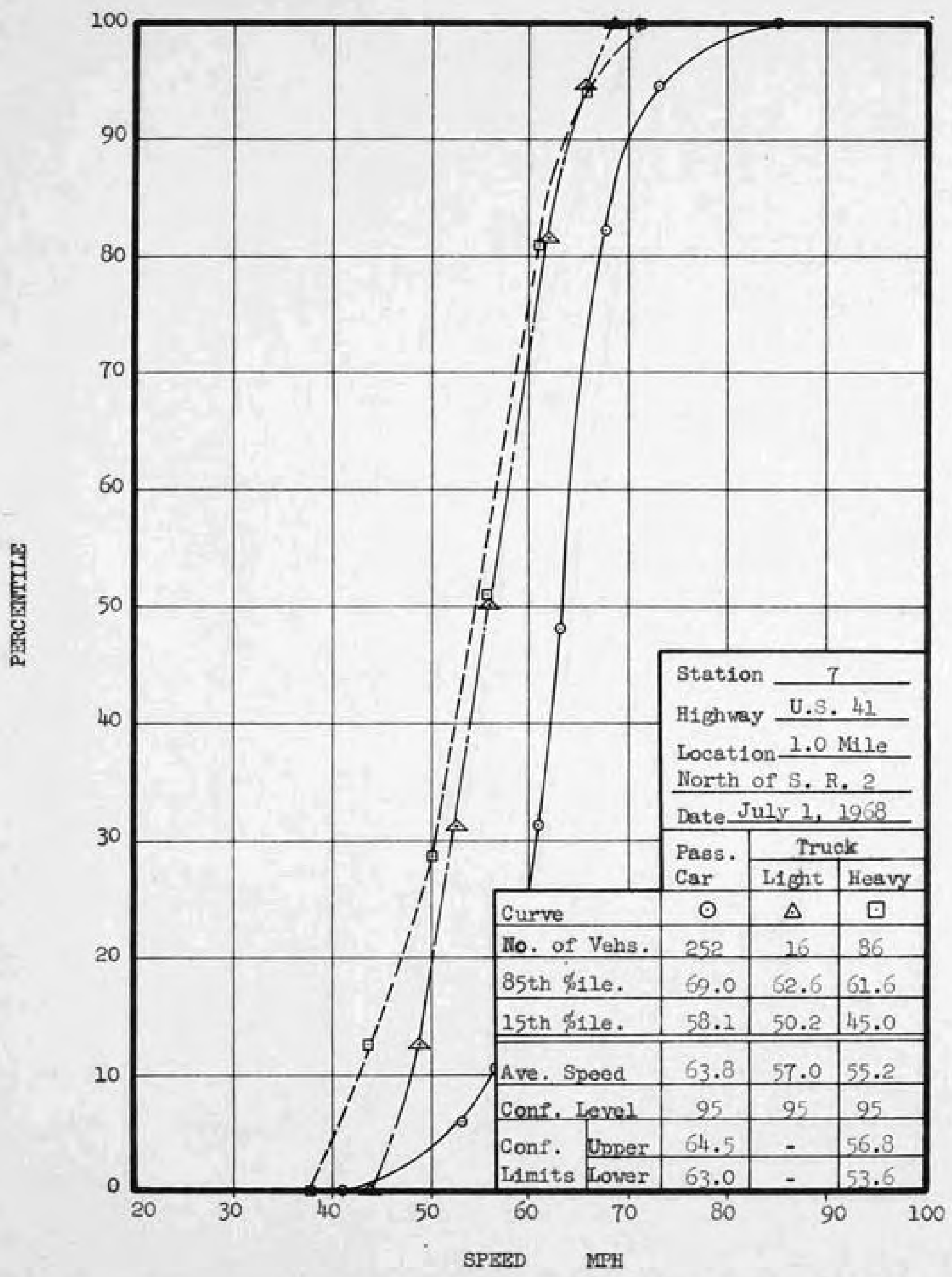




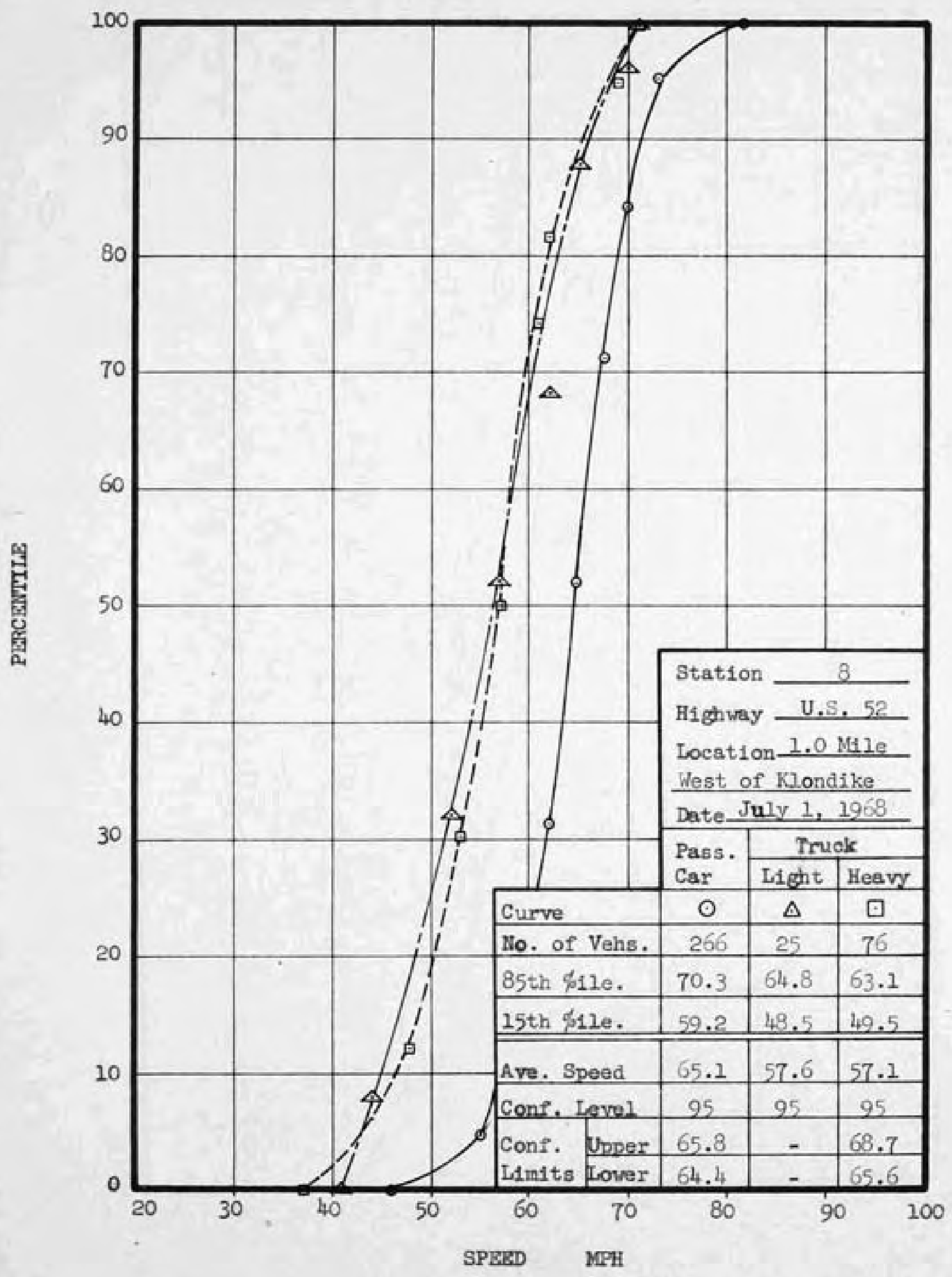




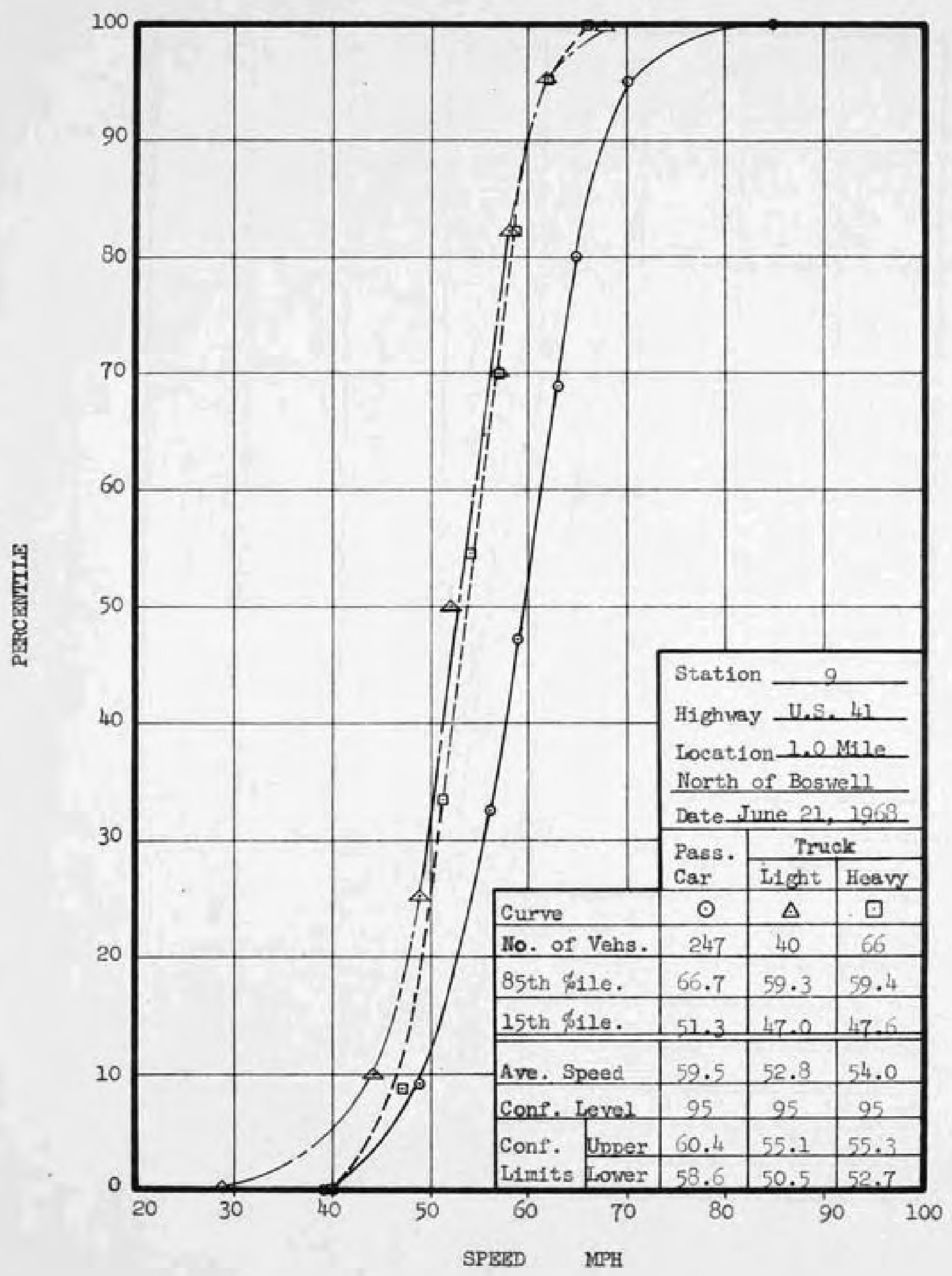




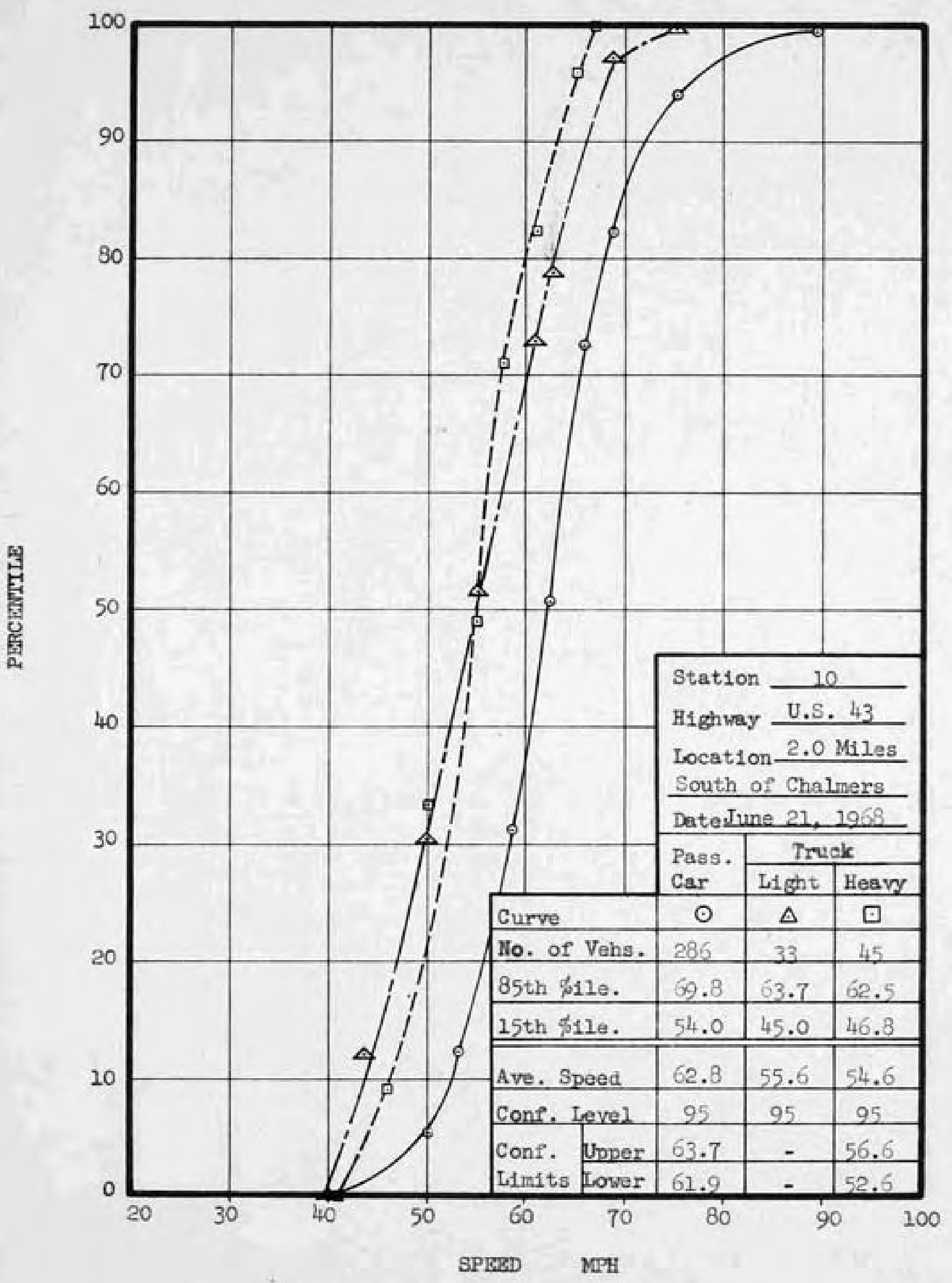




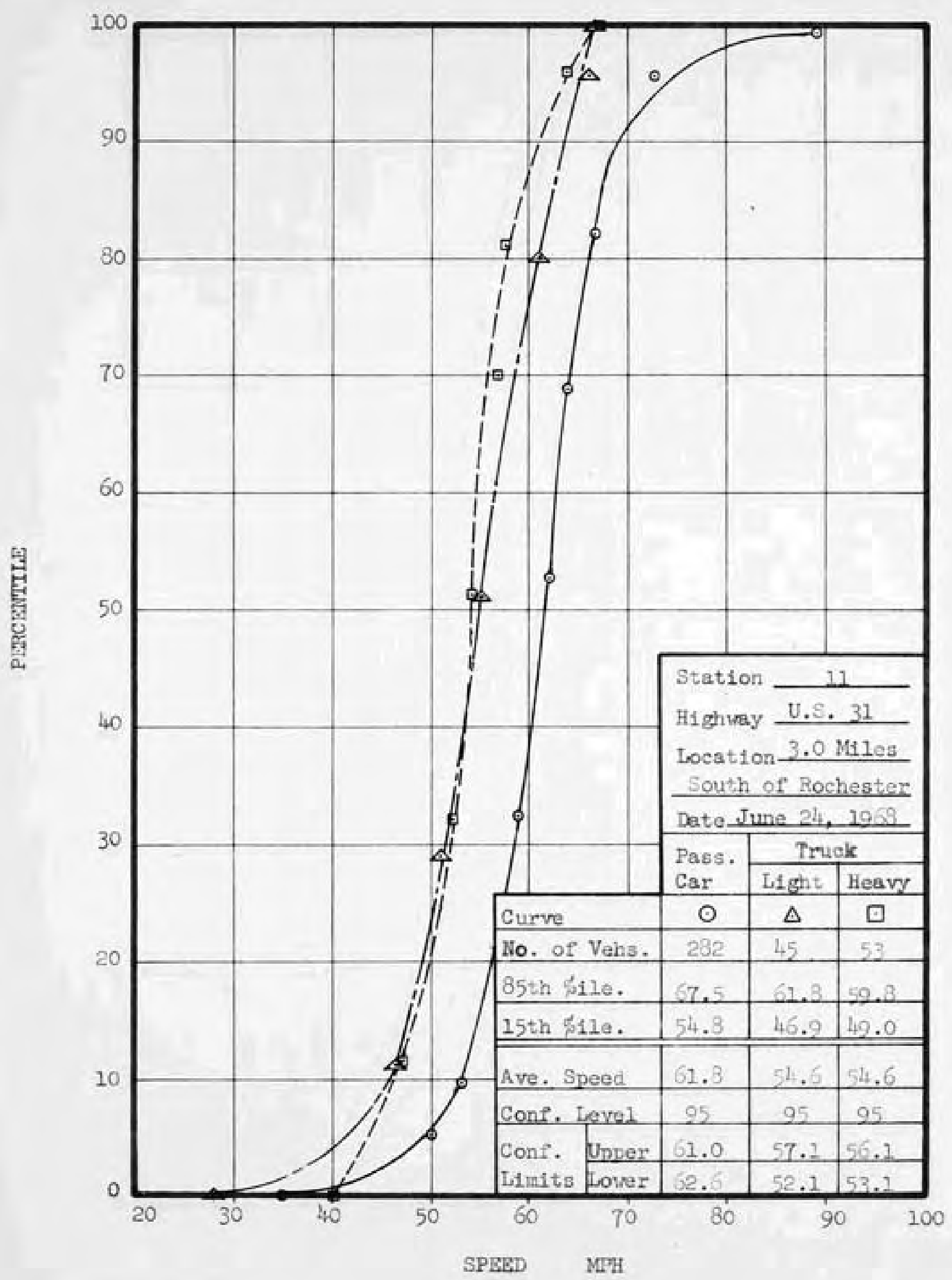




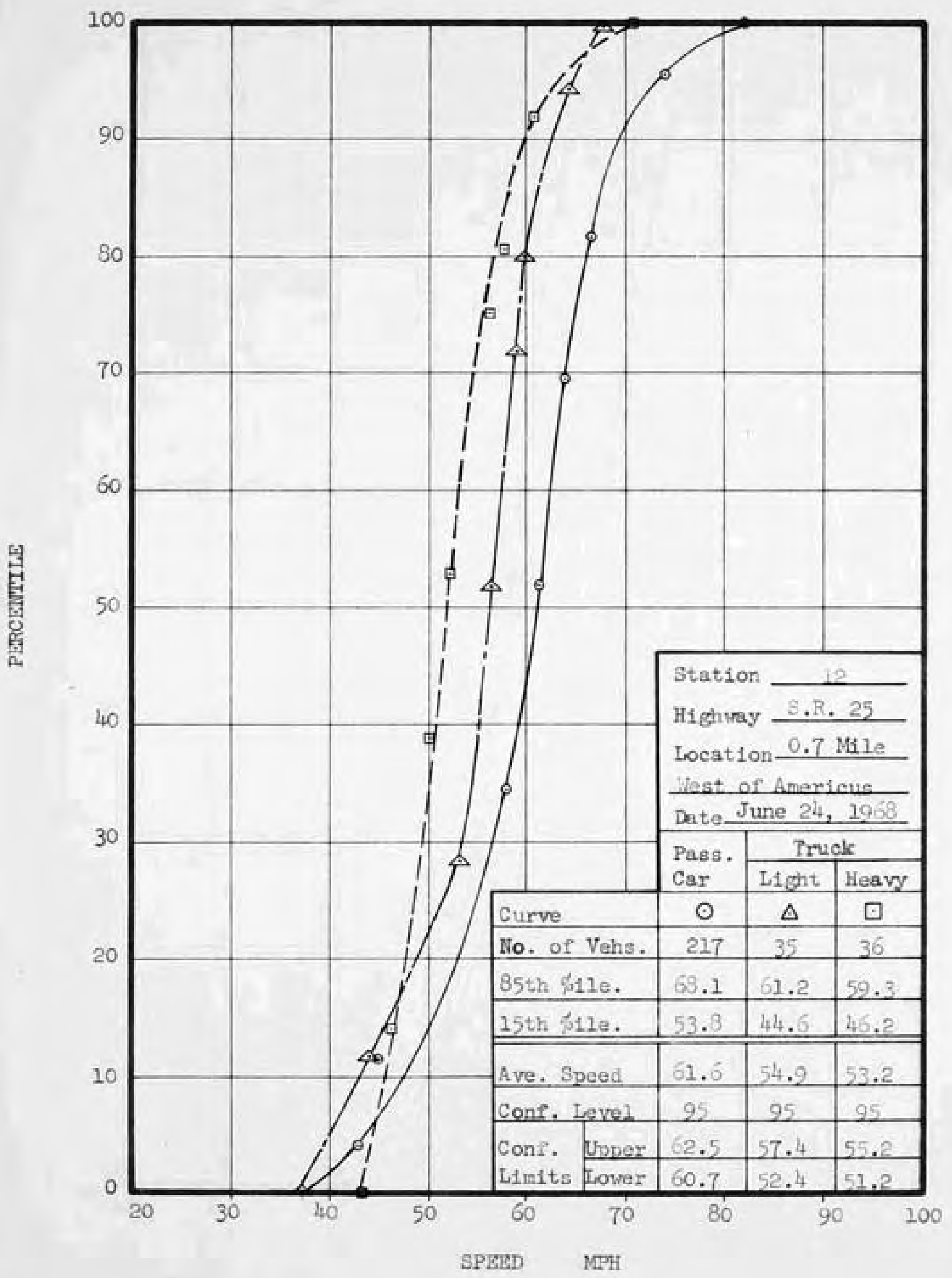




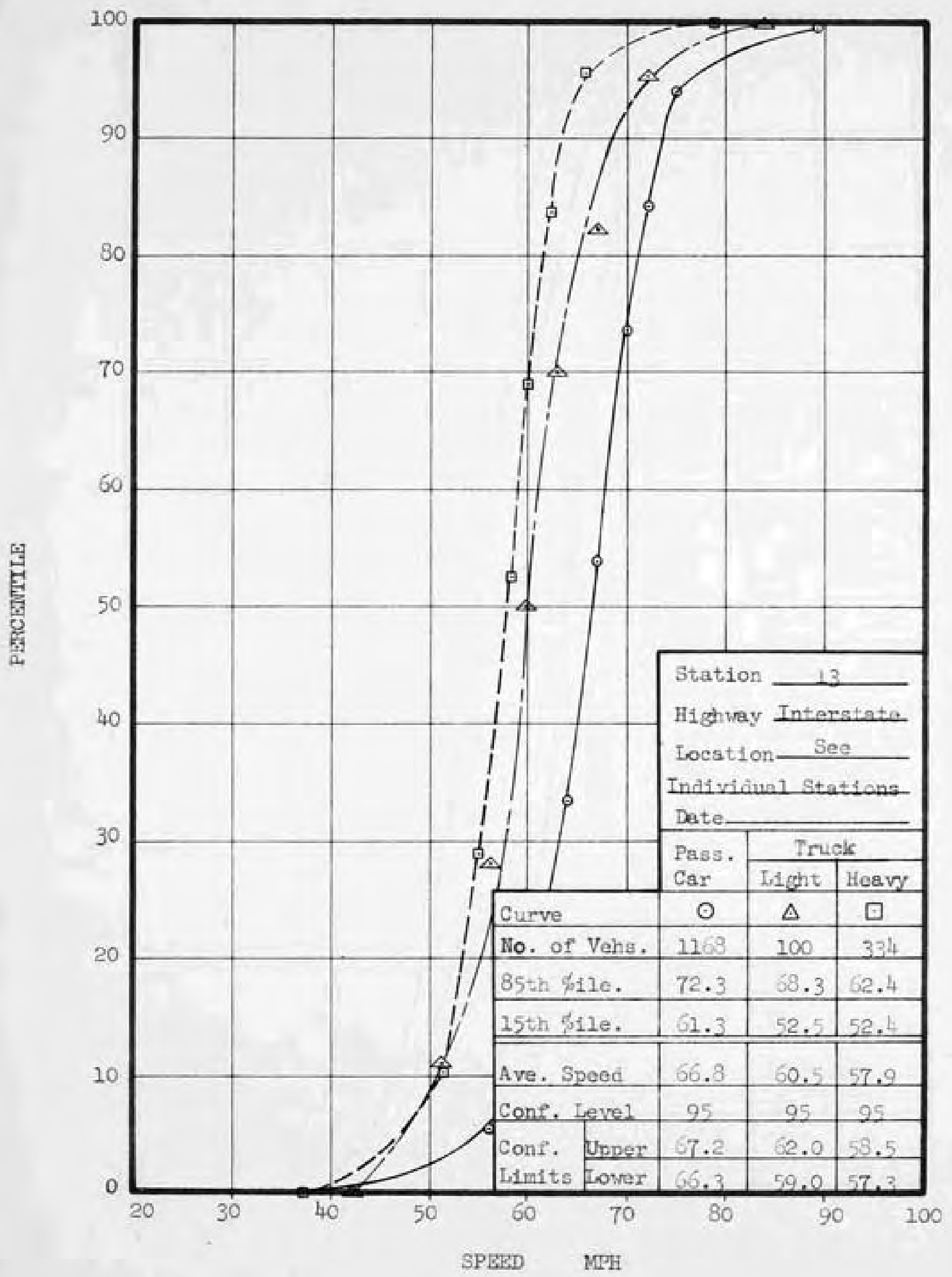




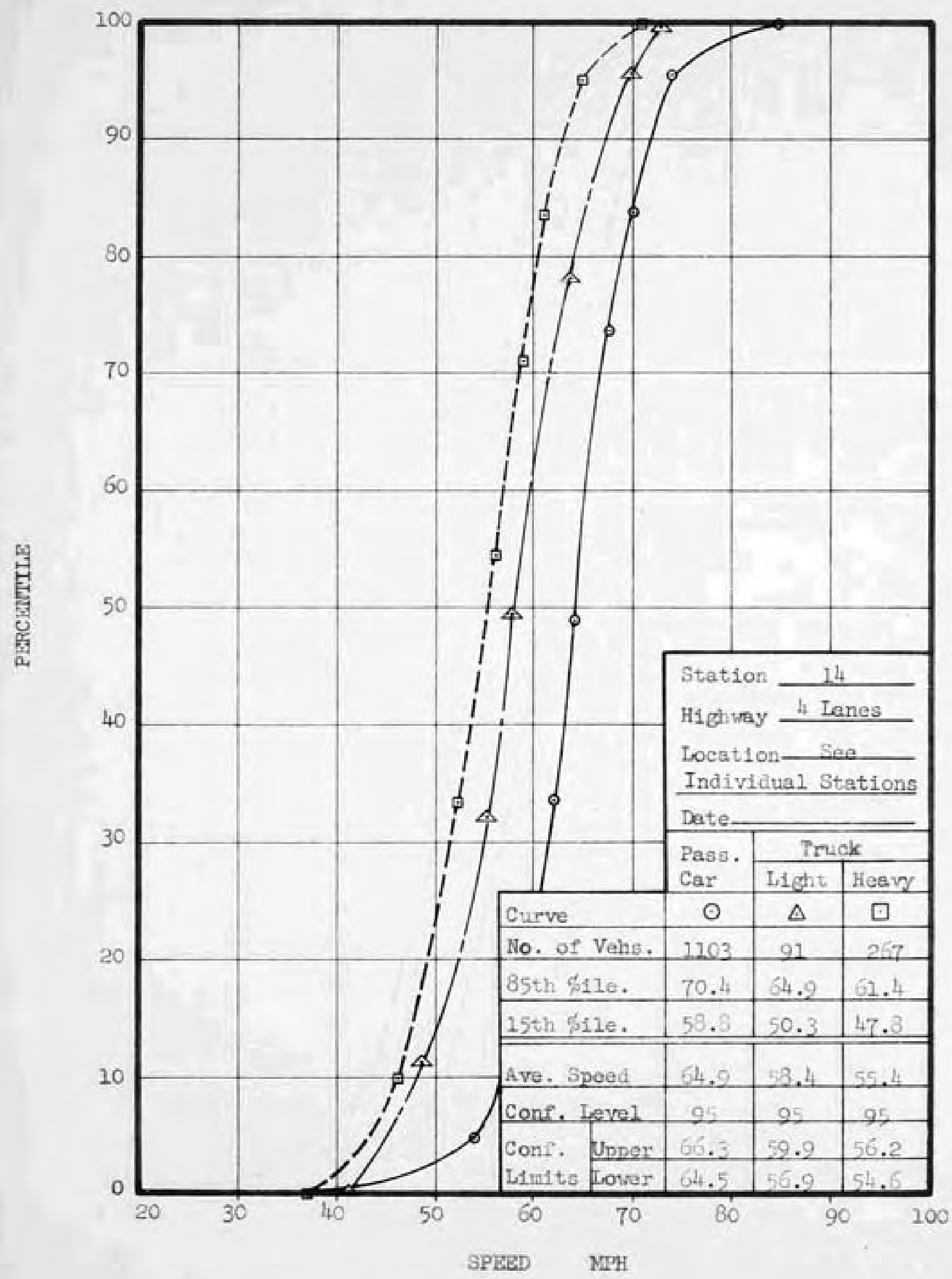




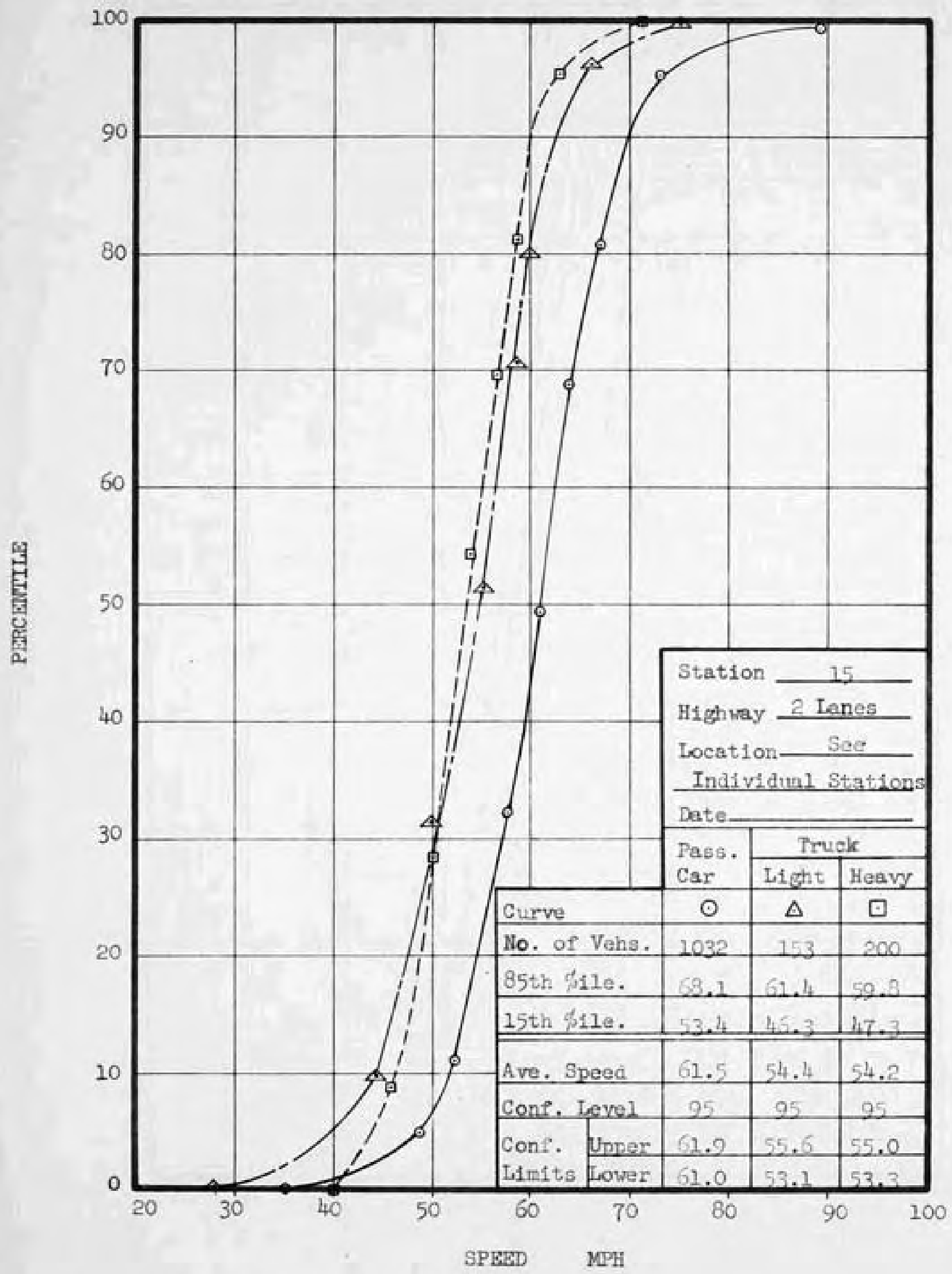




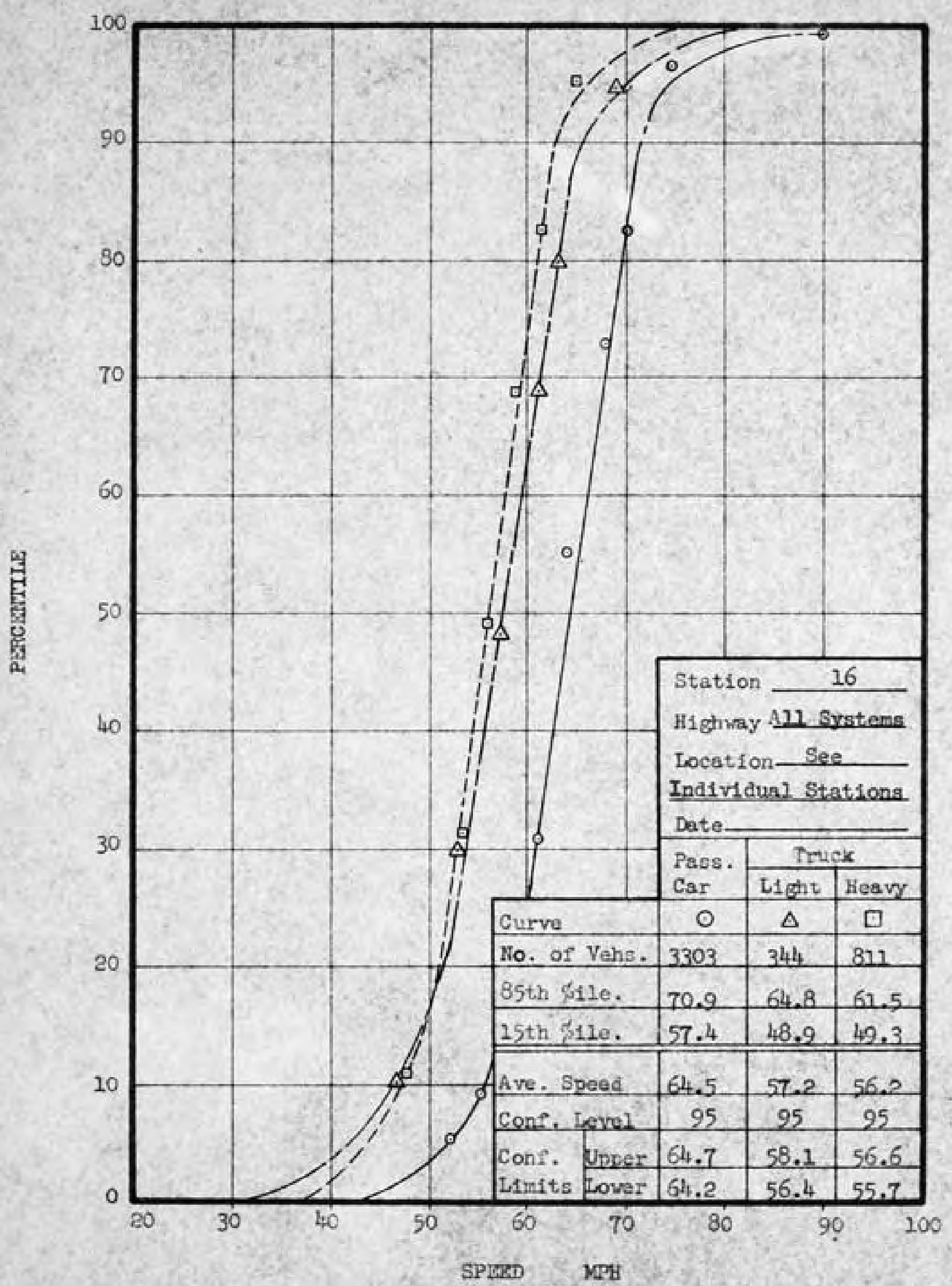

